\title{
Fermented food consumption in wild nonhuman primates and its ecological drivers
}

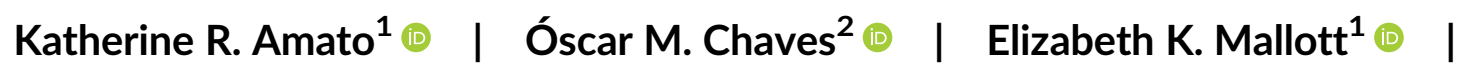

Timothy M. Eppley ${ }^{3,4}$ (1) | Filipa Abreu ${ }^{5}$ | Andrea L. Baden ${ }^{6,7}$ ( ) |

Adrian A. Barnett $^{8}$ | Julio Cesar Bicca-Marques ${ }^{9}$ (]) | Sarah A. Boyle ${ }^{10}$ |

Christina J. Campbell ${ }^{11}$ | Colin A. Chapman ${ }^{12,13,14}$ | María Fernanda De la Fuente ${ }^{5}$ ( ) |

Pengfei Fan ${ }^{15}$ | Peter J. Fashing ${ }^{16,17}$ | Annika Felton ${ }^{18}$ | Barbara Fruth ${ }^{19,20,21}$ ( ) |

Vanessa B. Fortes $^{22}$ (1) | Cyril C. Grueter ${ }^{23,24}$ (1) | Gottfried Hohmann ${ }^{25}$ |

Mitchell Irwin $^{26}$ (1) | Jaya K. Matthews ${ }^{24,27}$ | Addisu Mekonnen ${ }^{17}$ |

Amanda D. Melin ${ }^{28}$ (1) | David B. Morgan ${ }^{29}$ | Julia Ostner ${ }^{30,31}$ | Nga Nguyen ${ }^{16,17}$ |

Alex K. Piel $^{32}$ @ | Braulio Pinacho-Guendulain ${ }^{33,34}$

Erika Patricia Quintino-Arêdes ${ }^{9}$ ( ) | Patrick Tojotanjona Razanaparany ${ }^{35,36}$

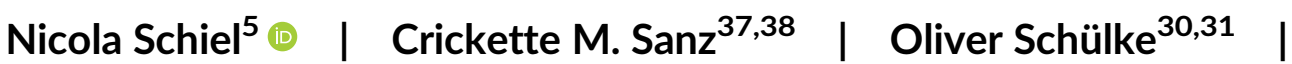

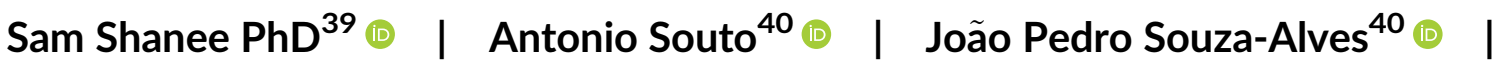

Fiona Stewart ${ }^{20}$ (1) | Kathrine M. Stewart ${ }^{21}$ | Anita Stone ${ }^{41}$ | Binghua Sun ${ }^{42}$ |

Stacey $\operatorname{Tecot}^{43}$ | Kim Valenta ${ }^{44}$ | Erin R. Vogel ${ }^{45}$ | Serge Wich ${ }^{20}$ | Yan Zeng ${ }^{46}$

${ }^{1}$ Department of Anthropology, Northwestern University, Evanston, Illinois

${ }^{2}$ Escuela de Biología, Universidad de Costa Rica, UCR, San José, Costa Rica

${ }^{3}$ Institute for Conservation Research, San Diego Zoo Global, San Diego, California

${ }^{4}$ Department of Anthropology, Portland State University, Portland, Oregon

${ }^{5}$ Department of Biology, Federal Rural University of Pernambuco, Recife, Pernambuco, Brazil

${ }^{6}$ Department of Anthropology, Hunter College of the City University of New York, New York, New York

${ }^{7}$ The New York Consortium in Evolutionary Primatology (NYCEP), City University of New York, New York, New York

${ }^{8}$ Amazon Mammals Research Group, National Amazon Research Institute (INPA), Manaus, AM, Brazil \& Department of. Zoology, Federal University of Pernambuco, Recife, Prince Edward Island, Brazil

'Laboratório de Primatologia, Escola de Ciências da Saúde e da Vida, Pontifícia Universidade Católica do Rio Grande do Sul, PUCRS, Porto Alegre, RS, Brazil

${ }^{10}$ Department of Biology, Rhodes College, Memphis, Tennessee

${ }^{11}$ Department of Anthropology, California State University Northridge, Northridge, California

${ }^{12}$ Department of Anthropology, Center for the Advanced Study of Human Paleobiology, George Washington University, Washington, District of Columbia

${ }^{13}$ School of Life Sciences, University of KwaZulu-Natal, Pietermaritzburg, South Africa

${ }^{14}$ Shaanxi Key Laboratory for Animal Conservation, Northwest University, Xi'an, China

${ }^{15}$ School of Life Sciences, Sun Yat-Sen University, Guangzhou, China

${ }^{16}$ Department of Anthropology and Environmental Studies Program, California State University Fullerton, Fullerton, California

${ }^{17}$ Centre for Ecological and Evolutionary Synthesis (CEES), University of Oslo, Oslo, Norway

${ }^{18}$ Southern Swedish Forest Research Centre, Swedish University of Agricultural Sciences (SLU), Alnarp, Sweden

${ }^{19}$ Department of Human Behavior, Ecology and Culture, Max-Planck-Institute for Evolutionary Anthropology, Leipzig, Germany

${ }^{20}$ School of Biological and Environmental Sciences, Liverpool John Moores University, Liverpool, United Kingdom

${ }^{21}$ Centre for Research and Conservation, Royal Zoological Society of Antwerp, Antwerp, Belgium 


\footnotetext{
${ }^{22}$ Laboratório de Primatologia, Departamento de Zootecnia e Ciências Biológicas, Universidade Federal de Santa Maria, Palmeira das Missões, RS, Brazil

${ }^{23}$ School of Human Sciences, The University of Western Australia, Perth, Australia

${ }^{24}$ Centre for Evolutionary Biology, School of Biological Sciences, The University of Western Australia, Perth, Australia

${ }^{25}$ Department of Human Evolution, Max Planck Institute for Evolutionary Anthropology, Leipzig, Germany

${ }^{26}$ Department of Anthropology, Northern Illinois University, DeKalb, Illinois

${ }^{27}$ Africa Research \& Engagement Centre, The University of Western Australia, Crawley, Western Australia, Australia

${ }^{28}$ Department of Anthropology and Archaeology, University of Calgary, Calgary, Canada

${ }^{29}$ Lester E. Fisher Center for the Study and Conservation of Apes, Lincoln Park Zoo, Chicago, Illinois

${ }^{30}$ Department of Behavioral Ecology, University of Goettingen, Goettingen, Germany

${ }^{31}$ Research Group Primate Social Evolution, German Primate Center, Leibniz Institute for Primate Research, Goettingen, Germany

${ }^{32}$ Department of Anthropology, University College London, London, United Kingdom

${ }^{33}$ Departamento de Ciencias de la Salud, Universidad Autónoma Metropolitana (UAM), Lerma, Mexico

${ }^{34}$ Centro Interdisciplinario de Investigación para el Desarrollo Integral Regional (CIIDIR), Unidad Oaxaca, Instituto Politécnico Nacional, Mexico City, Mexico

${ }^{35}$ Graduate School of Asian and African Area Studies, Kyoto University, Kyoto, Japan

${ }^{36}$ Department of Zoology and Animal Biodiversity, University of Antananarivo, Antananarivo, Madagascar

${ }^{37}$ Department of Anthropology, Washington University in St. Louis, St. Louis, Missouri

${ }^{38}$ Congo Program, Wildlife Conservation Society, Brazzaville, Congo

${ }^{39}$ Neotropical Primate Conservation, Cornwall, United Kingdom

${ }^{40}$ Departamento de Zoologia, Universidade Federal de Pernambuco, Recife, Pernambuco, Brazil

${ }^{41}$ Biology Department, California Lutheran University, Thousand Oaks, California

${ }^{42}$ School of Resource and Environmental Engineering, Anhui University, Hefei, China

${ }^{43}$ School of Anthropology, University of Arizona, Tucson, Arizona

${ }^{44}$ Department of Anthropology, University of Florida, Gainesville, Florida

${ }^{45}$ Department of Anthropology, Rutgers University, New Brunswick, New Jersey

${ }^{46}$ Animal Microecology Institute, College of Veterinary, Sichuan Agricultural University, Ya'an, China
}

\section{Correspondence}

Katherine R. Amato, Department of

Anthropology, Northwestern University,

Evanston, Illinois.

Email: katherine.amato@northwestern.edu

Funding information

Canadian Institute for Advanced Research

\begin{abstract}
Objectives: Although fermented food use is ubiquitous in humans, the ecological and evolutionary factors contributing to its emergence are unclear. Here we investigated the ecological contexts surrounding the consumption of fruits in the late stages of fermentation by wild primates to provide insight into its adaptive function. We hypothesized that climate, socioecological traits, and habitat patch size would influence the occurrence of this behavior due to effects on the environmental prevalence of late-stage fermented foods, the ability of primates to detect them, and potential nutritional benefits.
\end{abstract}

Materials and methods: We compiled data from field studies lasting at least 9 months to describe the contexts in which primates were observed consuming fruits in the late stages of fermentation. Using generalized linear mixed-effects models, we assessed the effects of 18 predictor variables on the occurrence of fermented food use in primates.

Results: Late-stage fermented foods were consumed by a wide taxonomic breadth of primates. However, they generally made up $0.01 \%-3 \%$ of the annual diet and were limited to a subset of fruit species, many of which are reported to have mechanical and chemical defenses against herbivores when not fermented. Additionally, latestage fermented food consumption was best predicted by climate and habitat patch 
size. It was more likely to occur in larger habitat patches with lower annual mean rainfall and higher annual mean maximum temperatures.

Discussion: We posit that primates capitalize on the natural fermentation of some fruits as part of a nutritional strategy to maximize periods of fruit exploitation and/or access a wider range of plant species. We speculate that these factors contributed to the evolutionary emergence of the human propensity for fermented foods.

\section{KEYWORDS}

climate, feeding ecology, fermentation, herbivore defense, human evolution

\section{1 | INTRODUCTION}

Food fermentation-the anaerobic microbial degradation of carbon compounds into ethanol and/or lactic acid-is a central part of human diet and culture (Tamang \& Kailasapathy, 2010). Humans from many cultures regularly incite or direct microbial fermentation of a wide range of foods that include meat and dairy products, grains, fruits, and vegetables (Battcock \& Azam-Ali, 1998; Campbell-Platt, 1994; Deshpande, 2000; Tamang et al., 2017). Such foods make up 20 to $40 \%$ of the global food supply (Campbell-Platt, 1994). Although not all fermented foods contain ethanol, the majority of anthropological fermented food research to date targets ethanol as an indicator of fermentation (e.g., Dominy, 2015; Dudley, 2002; Garnier \& Valamoti, 2016; Hayden et al., 2013; Kuijt, 2009; Liu et al., 2018; Milton, 2004; Ross et al., 2002; Smalley \& Blake, 2003).

Directed fermentation by humans has early origins. There is archaeological evidence that humans have engaged in directed fermentation of fruits and grains and stored the resulting ethanol in large quantities since $\sim 4300$ B.C., although some suggest a date as early as 12,500 cal BP (Garnier \& Valamoti, 2016; Hayden et al., 2013). Evolutionary changes in human genes for processing ethanol and for interacting with a major lineage of fermenting bacteria (Lactobacillales) are compatible with an even earlier association with fermented foods, dating back to the divergence of hominids from other primates at $\sim 10$ Mya (Carrigan et al., 2015; Janiak et al., 2020; Peters et al., 2019). Limited technology for processing and storing food at this time makes it likely that our hominid ancestors relied more heavily on naturally occurring fermented foods. However, some simple forms of directed fermentation, such as burying food items or submerging them in water (Speth, 2017), may have been possible.

Why humans have incorporated fermented products so prominently into their diet across their evolutionary history is unclear. Fermentation is an effective food preservative since it produces locally high concentrations of ethanol and lactic acid that ultimately prevent microbial growth and associated food spoilage (Boulton et al., 1999; Pretorius, 2000; Skinner et al., 1980; Thomson et al., 2005). Additionally, the physiological effects of consuming ethanol (i.e., intoxication) are believed to have facilitated social gatherings and rituals (Liu et al., 2018). Accordingly, the modern and ancient contexts in which fermented food use has been documented often suggest central roles of food preservation and socially motivated ethanol acquisition in driving the ubiquity of human fermented food use (Dominy, 2015; Dudley, 2002; Kuijt, 2009; Liu et al., 2018; Milton, 2004; Ross et al., 2002; Smalley \& Blake, 2003). However, given genetic evidence that human adaptations for fermented food consumption emerged before the technology associated with its directed production and storage (Carrigan et al., 2015; Janiak et al., 2020; Peters et al., 2019), fermented food consumption may have provided another selective advantage earlier in our evolutionary history.

Given their high sugar content, fruits often ferment naturally (Dominy, 2004; Duar et al., 2017; Dudley, 2002; Gorgus et al., 2016; Martinson et al., 2012; Nyanga et al., 2007; Ruiz Rodriguez et al., 2019; Weaver, 2016), making it likely that all frugivorous animals consume some minimum amount of fermented foods. However, overripe fruits in the late stages of fermentation commonly remain in food patches after other fruits have been depleted. As described above, fermentation is distinct from rot or decay in that it involves distinct microbes and precludes the production of most toxic microbial byproducts (except ethanol). Therefore, it has been suggested that fruits in the late stages of fermentation could have been a fallback food for increasingly terrestrial hominids during periods of low food availability in patchy woodland environments (Carrigan et al., 2015).

Foods in the late stages of fermentation could also convey nutritional benefits that provide a selective advantage to consumers yearround. Compared to unfermented foods, fermented foods have higher caloric, free amino acid, and vitamin content (Gobbetti et al., 1994; LeBlanc et al., 2013; Mitchell \& Herlong, 1986; NRC, 1998; Tamang et al., 2016). In the wild, many fermented foods contain embedded insects, which provide an additional protein source (Barnett et al., 2017; Braham, 2015; Hodge \& Arthur, 1996; Xiaoming et al., 2010). In addition, fermentation improves the digestibility of food by breaking down resistant starch, soluble fiber, toxins, and secondary plant metabolites (Binita \& Khetarpaul, 1997; Chaves-López et al., 2014; Gupta et al., 2015; Rollan et al., 2019). For example, some toxic foods, such as blowfish and cassava, can only be consumed after fermentation (Akinrele, 1964; Anraku et al., 2013). Together these properties not only directly affect consumer nutrient intake, but may also result in a more favorable balance among the nutrients of food, which in turn can play a critical role in food selection (Felton et al., 2009). Therefore, foods in the late stages of fermentation could 
have represented a critical nutritional resource to hominids, particularly as energetically expensive life-history traits such as long juvenile periods, short interbirth intervals, and large brains emerged across evolutionary time (Aiello \& Key, 2002; Antón et al., 2014; Leonard \& Robertson, 1992, 1997). The consumption of other high-quality diet items such as meat and cooked food has also been hypothesized to have provided essential nutritional resources for the development and maintenance of these traits in hominids (Aiello \& Wells, 2002; DeCasien et al., 2017; Wrangham, 2009; Wrangham \& ConklinBrittain, 2003).

Fermented foods contain live microbes, substrates for microbial metabolism, and microbial metabolites, which may affect consumer health and fitness either directly or indirectly through impacts on the microbiome (Jacobsen et al., 1999; Kim et al., 2016; Maldonado-Gómez et al., 2016; Marco et al., 2017). Given the broad effects of the microbiome on host metabolism (Oliphant \& Allen-Vercoe, 2019; Visconti et al., 2019), immune function (Al Nabhani \& Eberl, 2020), and neuroendocrine dynamics (Cryan et al., 2019; Sylvia \& Demas, 2018), fermented foods have the potential to affect consumer physiology in many ways. Beyond intoxication caused by excessive consumption of fermented foods with high ethanol content, none of these documented physiological effects are negative. Therefore, fermented food consumption could have provided a selective advantage to hominids in addition to the nutritional advantages discussed above. Indeed, studies of human fermented food use consistently demonstrate a range of improved health outcomes (e.g., Bourrie et al., 2016; Burton et al., 2017; Yartey et al., 1995). However, the wide variety of positive health effects that fermented foods can produce via the microbiome make it difficult to predict specific scenarios in which these properties would be most evolutionarily advantageous based on current knowledge.

Even in the context of nutrition, modern human technology, and cultural practices complicate our ability to evaluate the potential fitness benefits of human fermented food consumption. As a result, comparative data from nonhuman primates (hereafter primates) are essential for exploring the adaptive function of this behavior. By determining how pervasive consumption of late-stage fermented foods by wild primates is and the ecological contexts in which it occurs, we can begin to more accurately assess the ecological and evolutionary forces that drive it and contextualize it within human evolutionary history. Nevertheless, few studies on this subject have incorporated primate data.

A handful of comparative genetic analyses of physiological adaptations for fermented food consumption integrate data from multiple primate species (Carrigan et al., 2015; Janiak et al., 2020; Peters et al., 2019). Additionally, some behavioral research has investigated primate ethanol affinity in response to the Drunken Monkey Hypothesis (Dudley, 2002, 2004). This hypothesis posits that humans direct the production of fermented foods and consume them as a result of our affinity for ethanol, which stems from our evolutionary past as frugivorous primates that used ethanol as an olfactory and/or gustatory signal for energy-rich fruit (Dudley, 2002, 2004). Therefore, data from other primates have been used to test the relationship between frugivory and ethanol affinity. The results indicate that primates across the Order prefer solutions of $2 \%-5 \%$ ethanol over water (Dausch Ibañez et al., 2019; Gochman et al., 2016; Hockings et al., 2015; Kornet et al., 1990; Mandillo et al., 1998). However, data from spider monkeys (Ateles geoffroyi) indicate that sweet solutions are preferred over ethanol regardless of calorie content (Dausch Ibañez et al., 2019). Outside of this context, fermented food consumption is rarely mentioned in studies of primate feeding ecology, despite the fact that not all fermented foods contain ethanol but all of them likely confer a range of nutritional and health benefits to consumers.

As a first step to address this knowledge gap, we compiled qualitative data describing overripe fruit consumption from primate field studies around the world to estimate the minimum prevalence of late-stage fermented foods in wild primate diets, regardless of ethanol content, and the ecological contexts in which the consumption of these foods occurs. We hypothesized that local climate, primate socioecological traits, and habitat patch size (Table 1) would predict the prevalence of primate consumption of late-stage fermented foods. First, climate affects both the rate of fermentation and the rate of ethanol evaporation (Isu \& Njoku, 1998), thereby influencing the local prevalence of late-stage fermented foods and the probability that primates will detect them via olfaction (Dominy, 2004; Melin et al., 2019; Nevo \& Valenta, 2018). Therefore, we predicted that mean minimum annual temperature, mean maximum annual temperature, mean daily temperature, mean annual rainfall, elevation, and latitude and longitude would be associated with the occurrence of late-stage fermented food consumption in wild primates. Given that fruit ferments easily in nature (Dominy, 2004; Duar et al., 2017; Dudley, 2002; Gorgus et al., 2016; Martinson et al., 2012; Nyanga et al., 2007; Ruiz Rodriguez et al., 2019; Weaver, 2016), we predicted that primate species and populations with high percentages of fruit in their diets and low percentages of leaves and invertebrates would be more likely to encounter and consume late-stage fermented food. Since home range, social group size, body size, and encephalization quotients are often correlated with diet (Clutton-Brock \& Harvey, 1980; Dunbar \& Shultz, 2007, 2017; Kudo \& Dunbar, 2001), we also expected these variables to be associated with late-stage fermented food consumption. Finally, due to the relationship between habitat patch size and food availability more generally (Abbas et al., 2011; Fahrig, 2003; Laurance et al., 2000), we predicted that habitat patch size would predict the prevalence of late-stage fermented foods and their consumption.

\section{2 | MATERIALS AND METHODS}

\section{1 | Behavioral data collection}

KRA, YZ, and TME identified a group of researchers who had completed a wild primate field study of at least nine consecutive months using multiple approaches. We searched two general online databases (https://scholar.google.com, http://xueshu.baidu.com) using specific keywords such as "primate" and "diet" combined with primate family names one year at a time beginning with 2005. We also reviewed the literature cited in multiple primate ecology books (Brady \& Carville, 2012; Campbell et al., 2011; Davies \& Oates, 1994; 
Dudley, 2014; NRC, 2003; Rowe \& Myers, 2016; Strier, 2016). Finally, we flagged abstracts from the programs of primate conferences in 2018 and 2019, including the American Society of Primatologists and the American Association of Physical Anthropologists.

KRA asked 151 researchers with relevant field studies and current email contact information to report whether they had observed their study subjects consuming fermented foods (i.e., plant foods overripe or fermenting based on their color, physical traits, smell, or other useful indicators). These food items could be found on the ground, but this was not necessary for a food to be deemed "fermented." Many fruits consumed by primates are likely to have undergone some degree of fermentation (Dominy, 2004), but only late stages of fermentation with higher concentrations of ethanol and other microbial products (Biale, 1954) are likely to be identified using the conservative sensorial cues we employed here. For example, Astrocaryum standleyanum unripe and ripe fruits are reported to have $0 \%$ and $0.6 \%$ ethanol while fallen fruits have $0.9 \%$ ethanol and overripe fallen fruits have $4.5 \%$ ethanol (Dudley, 2004). Therefore, it is likely that we are excluding a substantial number of fermented foods from our analysis (e.g., floral nectar and fruits with other levels of maturity; Aleksey Maro, personal communication; Wiens et al., 2008; Weaver, 2016). However, our approach still represents an important contribution to this complex subject since foods that can be sensorially identified as being in the late stages of fermentation are more likely to have physiological effects on consumers as a result of higher concentrations of microbes and/or microbial by-products (Tamang et al., 2016). Systematic data describing chemical and microbial variables in wild fruits are necessary to more accurately quantify fermentation stages in wild food items and the probability of detection by foragers and observers. Because these traits likely vary across plant species, primate species, and environments, such an analysis is outside the scope of this study. Nevertheless, given that the ethanol content of the small number of ripe fruit species that have been measured in habitats occupied by wild primates is reported to range from $0.01 \%$ to $1.1 \%$ (Dominy, 2004; Dudley, 2004; Weaver, 2016), our conservative estimate is that late-stage fermented fruits in our study have an ethanol content $>1 \%$. No data exist to allow estimates of microbial biomass or concentrations of non-ethanol microbial by-products.

We collated data for 40 species of primates inhabiting 50 research sites (Table S1). While these data encompass a small percentage of all extant primate species $(7.9 \%, 40$ of 504 recognized species; Estrada et al., 2017), 11 of the 16 extant primate families were represented across all continents inhabited by primates, and we included both tropical and temperate environments. Therefore, we believe that our database fairly represents the phylogenetic and geographic diversity of the order Primates. Study duration ranged from 9 to 312 months (median = 15 months), and we used data from multiple social groups or communities of 18 species distributed across 13 sites. We included data describing the location and length of the study, the elevation, mean annual maximum and minimum temperatures, mean daily temperature, and mean annual rainfall of the study site, the mean contribution of fruits, leaves, and invertebrates to the diet of the study species, the frequency with which any fermented foods were consumed relative to total observation time, and any other relevant details about the types of foods consumed or associated behavior, such as seasonality or specific handling behaviors (Table $\mathrm{S} 1$ ).

\section{2 | Physical and chemical traits of consumed late-stage fermented foods}

For all late-stage fermented foods consumed, we compiled data from each study site or the literature describing the presence/absence of a tough husk or skin, relative fiber content, and presence/absence of secondary metabolites and their concentrations. We evaluated tough husks qualitatively. A relative assessment of fiber content compared to other fruits at the same site was possible for 35 fruits, and for 25 of these fruits, the nutritional data were available for that study site specifically. Secondary metabolite data were more difficult to compile. Quantitative data were available for 11 fruit species at three sites. For the rest of the fruits, we searched the literature using the fruit species name combined with terms such as "toxin" and "secondary metabolite." Because data describing secondary metabolite content in fruits is sparse, in many cases we had to rely on literature describing medicinal use that implied increased concentrations of identified or unidentified secondary metabolites. Using this approach, we were able to find evidence of the occurrence of secondary metabolites for 34 fruit species (Table 3).

\section{3 | Data analysis}

We assessed the influence of 18 predictor variables (Table 1) on the occurrence of late-stage fermented food consumption via generalized linear mixed-effects models (GLMM; Zuur et al., 2009) with a binomial distribution and logit link function using the function "Imer" of the R package Ime4 (Bates et al., 2015). We specified the occurrence of late-stage fermented food consumption as a binary response variable, all the predictor variables as fixed factors, and study site as a random factor to account for data from repeated measures of the same species in different social groups at the same site. In addition to socioecological, climate, and habitat patch size variables, we included study length in all of our models to determine if shorter studies were biased against what we assumed would be a relatively rare behavior (Souza-Alves et al., 2019). To avoid overparameterization and problems of convergence with the global model, we did not consider variable interactions (see Grueber et al., 2011). We also did not include variables describing primate taxonomy because limited replication of species reduced the power of the analysis to assess the impact of these variables.

Given differences in scale among the predictor variables, we standardized them using the "standardize" function of the package MuMln (Barton, 2020) as recommended by Grueber et al. (2011). We avoided multicollinearity problems by only including those variables with Variance Inflation Factors (VIF) $<3$ into the models (Zuur et al., 2009) using the "vifstep" function of the package usdm (Naimi et al., 2014). The seven variables with VIF $>3$ that we excluded from the global model were female 
TABLE 1 Potential predictors of fermented food consumption analyzed in this study

\begin{tabular}{|c|c|}
\hline Variable & Description \\
\hline \multicolumn{2}{|l|}{ Socioecological traits } \\
\hline 1. Percent leaves in diet & Proportion of immature and mature leaves in diet \\
\hline 3. Percent invertebrates in diet & Proportion of insects and other invertebrates in diet \\
\hline 4. Home range & Size of the home range for each study group (ha) \\
\hline 6. Male body mass & Adult male body mass $(\mathrm{kg})$ in each study species \\
\hline 7. Female body mass & Adult female body mass $(\mathrm{kg})$ in each study species \\
\hline 8. Female relative encephalization quotient & Endocranial volume $(\mathrm{cc})$ of the adult individuals divided by adult female body mass $(\mathrm{kg})$ \\
\hline 9. Male relative encephalization quotient & Endocranial volume (cc) of the adult individuals divided by adult male body mass (kg) \\
\hline \multicolumn{2}{|l|}{ Climate } \\
\hline 13. Mean annual maximum temperature & Annual mean maximum temperature $\left({ }^{\circ} \mathrm{C}\right)$ recorded by the local meteorological stations \\
\hline 14. Mean annual minimum temperature & Annual mean minimum temperature $\left({ }^{\circ} \mathrm{C}\right)$ recorded by the local meteorological stations \\
\hline 15. Mean daily temperature & Daily mean temperature $\left({ }^{\circ} \mathrm{C}\right)$ recorded by the local meteorological stations \\
\hline 16. Elevation & Representative elevation $(m)$ of study site \\
\hline
\end{tabular}

Habitat quality

17. Habitat size

Size of the habitat occupied by each study group (ha); proxy for fragmentation

Sampling Effort

18. Study length

Number of months during which data were collected

body mass, male body mass, male relative encephalization quotient, percentage of leaves in the diet, percentage of invertebrates in the diet, mean daily temperature, and elevation.

We selected models with an $\Delta \mathrm{AICc}<2$ as the most parsimonious (Grueber et al., 2011). Given the occurrence of multiple equally parsimonious models, we also performed full-model averaging on all models with an $\Delta \mathrm{AlCc}<2$ to account for model uncertainty and to identify the best predictors of patterns of late-stage fermented food consumption in our data set (Grueber et al., 2011). We used the "model.avg" function of the R package MuMln to identify the averaged model and the predictor weight $\left(\sum w_{i}\right)$ of each variable. We determined the coefficient of determination for each model with $\Delta \mathrm{AICc}<2$ using the MuMIn "r.squaredGLMM" function. We performed all statistical analyses in R 3.6.3 (R CoreTeam, 2020).

\section{$3 \mid$ RESULTS}

\section{1 | Occurrence of late-stage fermented food consumption in wild primates}

Out of 40 species of wild primates studied at 50 sites, 15 species (37.5\%) were reported to consume late-stage fermented foods at 23 sites in 12 countries across four continents (Figure 1). Overall, latestage fermented food consumption occurred infrequently (Table 2, S1). We estimated that it constituted from $0.01 \%$ to $3 \%$ of the annual diet in most groups, although there were seasonal differences. For example, we found that late-stage fermented fruits could account for as much as $15 \%$ of the feeding records of Cebus imitator and Alouatta guariba clamitans during some seasons. For some primates, such as A. guariba clamitans, these seasons represented periods of low food availability (VBF personal observation), whereas, for many others, such as $C$. imitator, they did not (EKM personal observation). While we recorded late-stage fermented food consumption in all our Pan paniscus and C. imitator social groups (three and seven, respectively), not all populations or social groups of the other species studied exhibited this behavior.

\section{2 | Main sources of late-stage fermented foods and behavioral strategies used}

Late-stage fermented food consumption was limited to fruits (Figure 2, Tables 2, 3, S1). The richness of late-stage fermented fruits exploited ranged from one to nine fruit species for a given primate species (Tables 2, 3, S1). Pan paniscus exhibited the highest richness of late-stage fermented fruit species in the $\operatorname{diet}(N=9$ fruit species), followed by Ateles geoffroyi ( $N=8)$, Alouatta guariba clamitans $(N=7)$, and Cebus imitator ( $N=5$; Table 2). The remaining primate species exploited between one and three fruit species (Table 2).

At least 31 of the 44 fruit species that were consumed in the late stages of fermentation have defenses in the form of difficult-tobreak tough husks/skins ( $N=16$ ) or secondary metabolites, such as alkaloids, acetogens, saponins, and tannins ( $N=25$; Table 3 ). Almost 


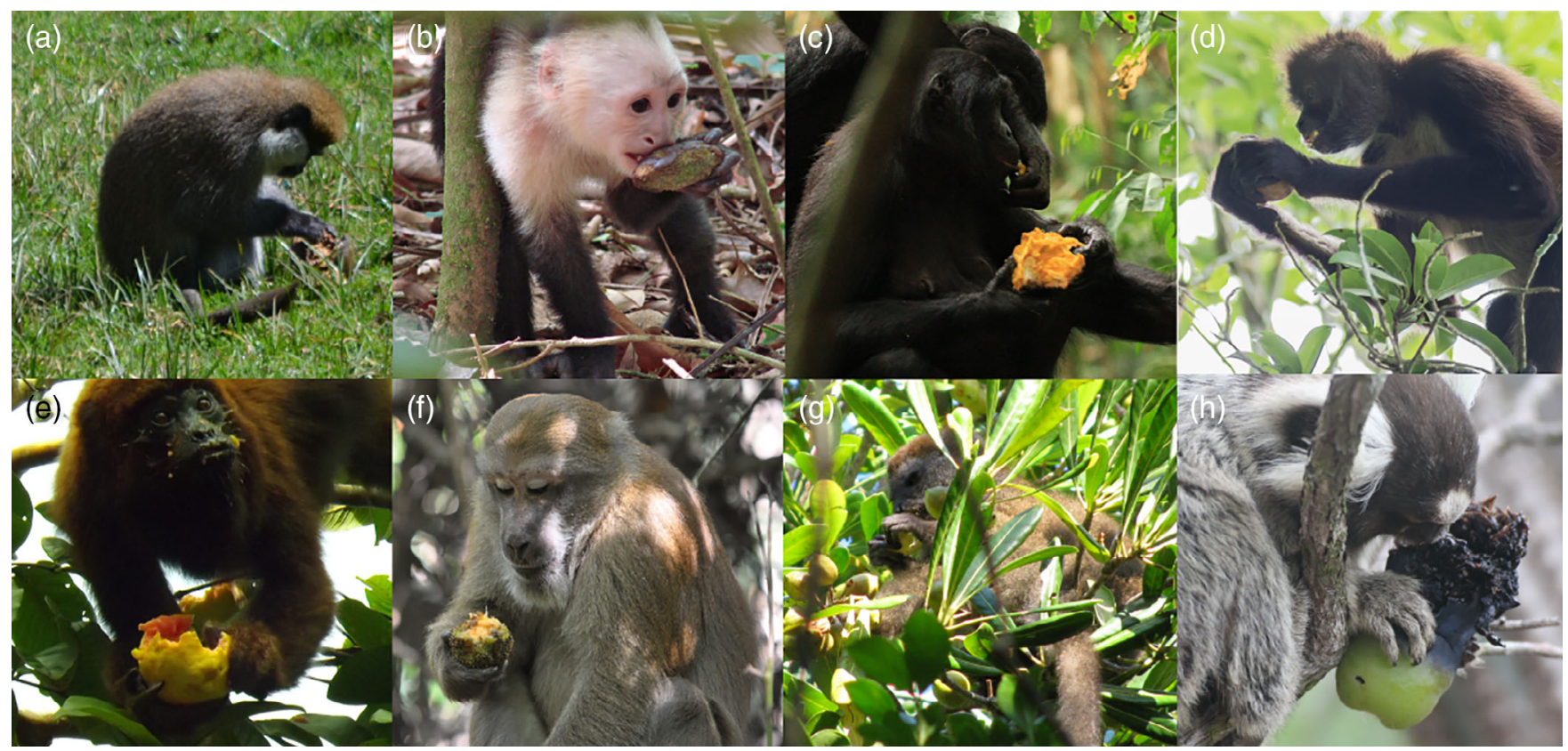

FIGURE 1 Wild primates consuming fermented fruits. (a) Chlorocebus djamdjamensis consuming L. abyssinica at Kokosa, Ethiopia; credit Addisu Mekonnen (b) Cebus capucinus imitator consuming D. oleifera at La Suerte Biological Field Station, Costa Rica; credit: Liz Rasheed (c) Pan paniscus consuming A. mannii at LuiKatole, Democratic Republic of Congo; credit Gottfried Hohmann (d) Ateles geoffroyi consuming M. zapota at Punta Laguna, Mexico; credit Fabrizio Dell'Anna (e) Alouatta guariba clamitans consuming P. guajava at Parque São Paulo, Brazil; credit Claudio Godoy (f) Macaca assamensis consuming N. cadamba at Phu Khieo Wildlife Sanctuary, Thailand; credit Oliver Schülke (g) Hapalemur meridionalis consuming Uapaca sp. at Mandena, Madagascar; credit Tim Eppley (h) Callithrix jacchus consuming P. pachycladus at Baracuhy Biological Field Station, Brazil; credit: Filipa Abreu

all fruits (95\%) were consumed both ripe/unfermented and overripe/ fermented (Table 3). In some cases, late-stage fermented fruits were only consumed when the patch was depleted of ripe fruits (Table S1). We also reported cases in which very ripe or late-stage fermented fruits appeared to be preferred over semi-ripe and unripe fruits. Specifically, Cebus imitator at La Suerte, Costa Rica, was observed frequently knocking ripe Dipteryx oleifera (Fabaceae) fruits to the ground and returning up to 2 weeks later to consume them (up to $15 \%$ of feeding time seasonally, EKM personal observation). These fruits were never consumed unfermented by the capuchins. Eulemur fulvus at Ampijiroa, Madagascar (up to 5\% of feeding time seasonally, PTR personal observation) and Ateles geoffroyi at Punta Laguna, Mexico (up to $1 \%$ of feeding time seasonally, BPG personal observation) were also reported to drop fruits to the ground and return to feed on them later. However, unlike the capuchins, both lemurs and spider monkeys consumed the target fruits in different stages of ripening, although the lemurs appeared to prefer fallen fruits over those on the trees since they would consume fallen fruits first when both were available.

\section{3 | Main primate predictors of late-stage fermented fruit consumption}

Only climate and habitat patch size were strong predictors of late-stage fermented food consumption in wild primates. Other socioecological traits did not contribute substantially to any of our top-ranked models. We found six GLMMs equally parsimonious $(\Delta \mathrm{AIC}<2)$ for explaining the observed patterns in late-stage fermented food consumption (Table 4). These models included mean maximum and minimum annual temperature, mean annual rainfall, habitat patch size, mean minimum annual temperature, longitude, home range size, and female relative encephalization quotient and explained $\sim 99 \%$ of the observed variance (Table 4). However, only mean annual maximum temperature, rainfall, and habitat patch size were present in all six models. The model with the strongest empirical support $(\triangle \mathrm{AICC}=0.00)$ included these three variables and mean minimum annual temperature (Table 4). The averaged model explained $99 \%$ of the observed variance, and late-stage fermented food consumption was only strongly negatively predicted by annual mean rainfall and and positively predicted by mean annual maximum temperature and habitat patch size (Table 4).

\section{DISCUSSION}

We found that wild primates from all major evolutionary lineages consume foods in the later stages of fermentation, although the behavior is relatively infrequent and limited to only a few species of fruits at the sites where we recorded it. Additionally, climatic and environmental variables generally predict the occurrence of late-stage fermented food consumption better than socioecological variables. Specifically, late-stage fermented food consumption is more common in hotter, drier environments and larger, presumably less fragmented, habitats. 
TAB LE 2 Wild primate species reported to consume fermented fruits

\begin{tabular}{|c|c|c|c|c|c|c|c|}
\hline Primate species & Family & Country & Study site ${ }^{a}$ & \# groups & Fruits $^{b}$ & $\% \mathrm{TFT}^{\mathrm{c}}$ & Location $^{d}$ \\
\hline Alouatta caraya & Atelidae & Brazil & ECB & 1 & 1 & - & $\mathrm{T}$ \\
\hline Alouatta guariba clamitans & Atelidae & Brazil & CISM, RE, PSP, PEI & 7 & $1-7$ & $<0.5-2$ & $\mathrm{~T}, \mathrm{G}$ \\
\hline Callithrix jacchus & Callitrichidae & Brazil & BBFS & 1 & 16,17 & 0.5 & G \\
\hline Cebus imitator & Cebidae & Costa Rica & LSBFS, SSR & 6 & $12,18-21$ & $<1$ & G \\
\hline Chlorocebus djamdjamensis & Cercopithecidae & Ethiopia & Kokosa & 1 & 22 & $<1$ & G \\
\hline Macaca assamensis & Cercopithecidae & Thailand & PKWS & 1 & 23,24 & 0.01 & G \\
\hline Papio anubis & Cercopithecidae & Uganda & KNP & 1 & 25 & $<3$ & G \\
\hline Pan troglodytes troglodytes & Hominidae & Republic of Congo & Goualougo & 1 & $26-28$ & - & G \\
\hline Pan paniscus & Hominidae & DRC & LuiKotale, Lomako & 3 & $29-37$ & - & $\mathrm{T}$ \\
\hline Hapalemur meridionalis & Lemuridae & Madagascar & Mandena & 1 & 43,44 & $<0.01$ & $\mathrm{~T}$ \\
\hline Total $=15$ & 6 & 12 & 23 & 34 & 44 & & \\
\hline
\end{tabular}

${ }^{a}$ Study sites: $\mathrm{ECB}=$ Estancia Casa Branca, CISM = Campo de Instruição de Santa Maria, RE = Reserva Econsciência, PSP = Parque São Paulo, PEI = Parque Estadual de Itapuã, $\mathrm{PL}=$ Punta Laguna, RBMA = Reserva de la Biósfera Montes Azules, EPO = Ejido Zamora Pico de Oro, BCl = Barro Colorado Island, BBFS = Baracuhy Biological Field Station, LSBFS $=$ La Suerte Biological Field Station, SSR = Sector Santa Rosa, Area de Conservacion Guanacaste, PKWS = Phu Khieo Wildlife Sanctuary, KNP = Kibale National Park.

${ }^{\mathrm{b}}$ Fruit species: 1 = Phytolacca dioica, 2 = Diospyros kaki, 3 = Citrus reticulata, 4 = Campomanesia xanthocarpa, 5 = Eugenia rostrifolia, $6=$ Enterolobium contortisiliquum, 7 = Psidium guajava, 8 = Manilkara zapota, 9 = Enterolobium cyclocarpum, $10=$ Spondias pupurea, $11=$ S. radlkoferi, $12=$ S. mombin, 13 = Astrocaryum standleyanum, 14 = Quararibea asterolepis, 15 = Ampelocera hottlei, 16 = Annona muricata, $17=$ Pilosocereus pachycladus,18 = Dipteryx oleifera, 19 = Manilkara chicle, 20 = Stemmadenia obovata, $21=$ Byrsonima crassifolia, $22=$ Lagenaria abyssinica, $23=$ Neolamarkia cadamba, $24=$ Gmelina arborea, 25 = Mimusops sp., $26=$ Treculia Africana, $27=$ Gambeya lacourtiana, $28=$ Detarium macrocarpum, $29=$ Parinari congensis, $30=$ Gilbertiodendron dewevrei, $31=$ Mammea africana, $32=$ Guibourtia demeusei, $33=$ Dialium angolense, $34=$ D. pachyphyllum, $35=$ D. corbisieri, $36=$ Anonidium mannii, 37 = Pouteria cf. malaccensis, $38=$ Klainedoxa gabonensis, $39=$ Diospyros pseudomalabarica, $40=$ Ficus sundaica, $41=$ Landolphia myrtifolia, $42=$ Vangueria madagascariensis, 43 = Uapaca sp., 44 = Syzygium emirnense.

'Percentage of total feeding time. No available information is indicated with -.

dLocation where food consumed: $\mathrm{T}$ = tree, $\mathrm{G}=$ ground.

As fermentation is a continuous process, future studies should analyze the chemical and microbial properties of the fermented fruits consumed at different stages by the primates to improve the resolution of these relationships. However, our findings provide an important foundation for understanding the ecological and evolutionary forces that drive fermented food consumption in primates and offer new insights into the emergence of this behavior in humans.

\subsection{Occurrence of late-stage fermented food consumption in wild primates}

First, although reports of fermented food consumption are rare in most studies of wild primate feeding ecology, this behavior is probably pervasive across the Order. We observed late-stage fermented food consumption in more than one-third of the primate species for which we received data. However, given that our data were biased toward late-stage fermentation and many fermented foods consumed by primates cannot be identified by researchers without chemical analyses, it is likely that the prevalence of fermented food consumption among wild primates is even higher. Fruits consumed by primates commonly ferment naturally despite no clear signs to observers that fermentation has occurred (Dominy, 2004; Dudley, 2002; Aleksey Maro, personal communication; Weaver, 2016). Given that most primates, even those considered leaf-eaters, rely heavily on fruit during at least part of the year (Campbell et al., 2011; Rowe, 2018; Sussman, 1991), it is likely that most primates regularly consume fermented foods. This scenario becomes more probable when we consider the fact that other foods such as nectar or gums may also often ferment despite being difficult to observe (e.g., Wiens et al., 2008). Because the relative concentrations of ethanol and other microbial products at different stages of fermentation-and the likelihood of perception by foraging primates-are likely to vary by plant species, primate species, and habitat, quantitative data describing these variables for a range of food items are necessary to better define fermentation stages in wild foods, and to test the extent to which primate ecology varies with food fermentation stage. This area presents exciting opportunities for future research.

Nevertheless, we do not expect that all primates consume fermented fruits. For instance, primates of the subfamily Colobinae, 


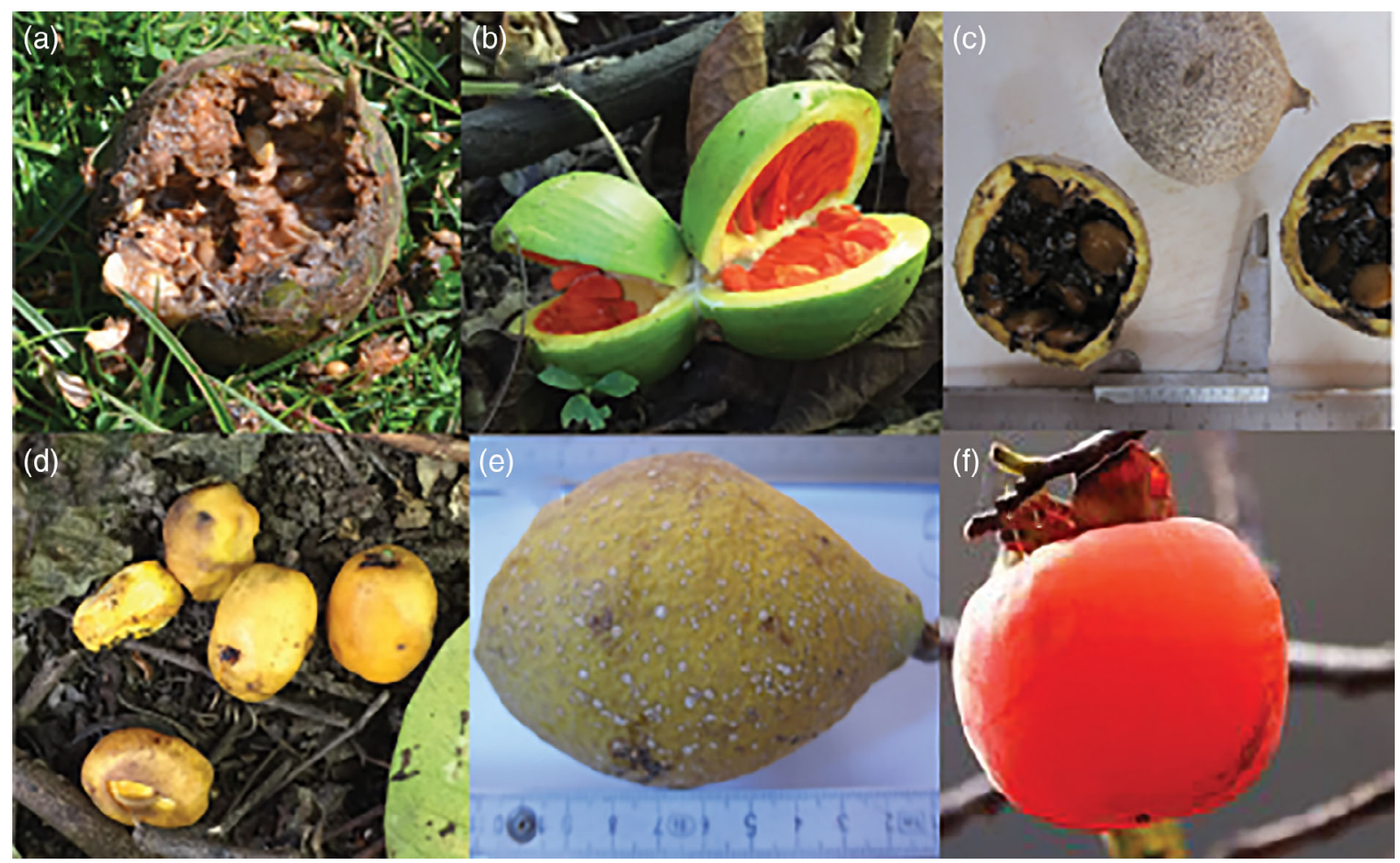

FIGURE 2 Fruits consumed fermented by wild primates. (a) Lagenaria abyssinica, credit: Addisu Mekonnen (b) Stemmadenia obovata, credit: Amanda Melin (c) Vangueria madagascariensis, credit: Tojotanjona Razanaparany (d) Spondias mombin, credit: Amanda Melin (e) Landolphia myrtifolia, credit Tojotanjona Razanaparany (f) Diospoyros kaki, credit Bingua Sun

which are physically unable to consume large amounts of ripe fruits as a result of their sacculated foregut (Davies \& Oates, 1994), as well as immature fruit specialists, such as the Neotropical Pitheciinae, were not observed consuming fermented fruit (at least not clearly overripe fruits) in any context in this study. Additionally, the physical nature of some habitats can reduce access to fermented fruits. For example, while not represented in our data set, swamps and riverbank forests reduce opportunities for fruit fermentation on the ground, and fruits in these habitats are often water-dispersed and rarely fleshy and easily fermentable (López, 2001).

\section{2 | Ecological contexts associated with late-stage fermented food consumption by wild primates}

Despite how relatively common late-stage fermented fruit consumption appears to be throughout the Order Primates, we found that it is selectively employed in specific ecological contexts. Although most primates include many fruit species in their diets, in most cases only one or two fruit species were consumed in the late stages of fermentation by a given primate population or social group. In some cases, this pattern appeared to be a result of primates extending the utility of a fruit patch. For example, in the rare instances when Pongo pygmaeus was observed consuming late-stage fermented fruits, it was after the patch had been depleted by other frugivores (ERV personal observation). Alternatively, some primates, such as groups of Alouatta guariba clamitans in Santa Maria municipality, Southern Brazil, appeared to rely on late-stage fermented fruits during periods of low or altered food availability (VBF personal observation). Similarly, Ateles geoffroyi on Barro Colorado Island, Panama utilized late-stage fermented Quararibea asterolepis during a period of unusual fruiting patterns associated with the previous year's El Niño event, as did other frugivorous mammals and birds (Campbell, 2000). These potential uses of late-stage fermented foods as fallback foods are in line with previous hypotheses in other contexts (Carrigan et al., 2015).

Other primates appeared to use fermentation to increase fruit edibility. Many fruits contain secondary metabolites, and in some cases they may reach sufficient levels to have meaningful physiological effects if consumed in large quantities (Cipollini \& Levey, 1997; Janzen, 1983). At least two-thirds of the fruit species consumed in the late stages of fermentation by wild primates in this study had mechanical or chemical herbivore defenses when unfermented. For seven of these species, primates were reported to reject fruits unless they were very ripe or fermented. Pan troglodytes has been previously shown to preferentially consume ripe fruits of plant species whose unripe fruits have high levels of tannins since ripening reduces tannin content (Wrangham \& Waterman, 1983). Therefore, it is possible that fermentation was used by some of our study subjects in a similar way to break down plant herbivore defenses. For example, Dipteryx oleifera, has a hard husk that can only be breached by Cebus imitator when fermented (EKM personal observation). 


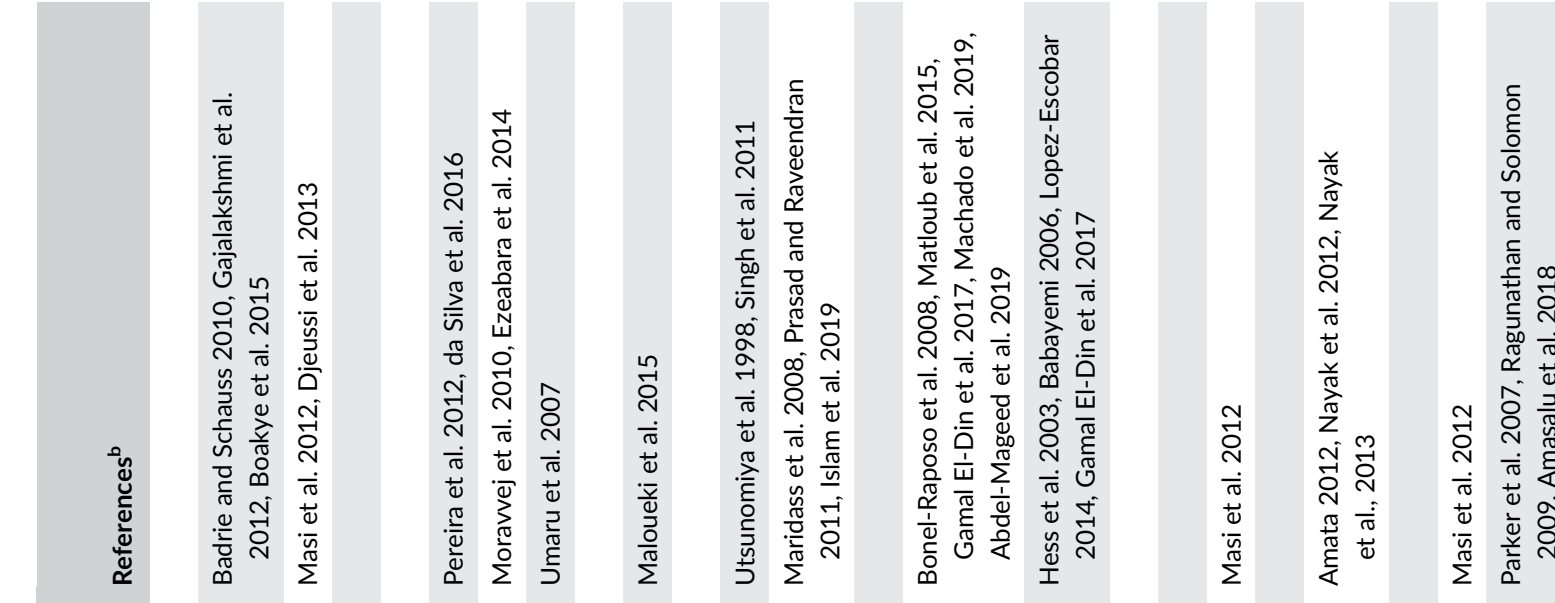

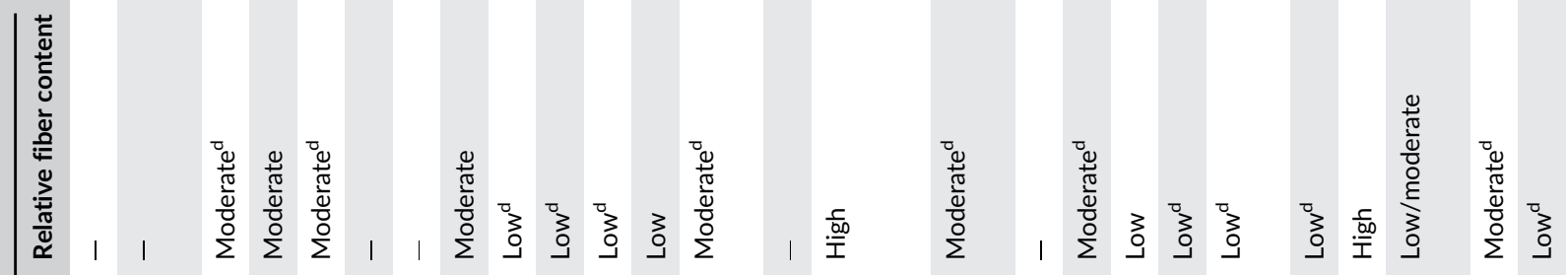

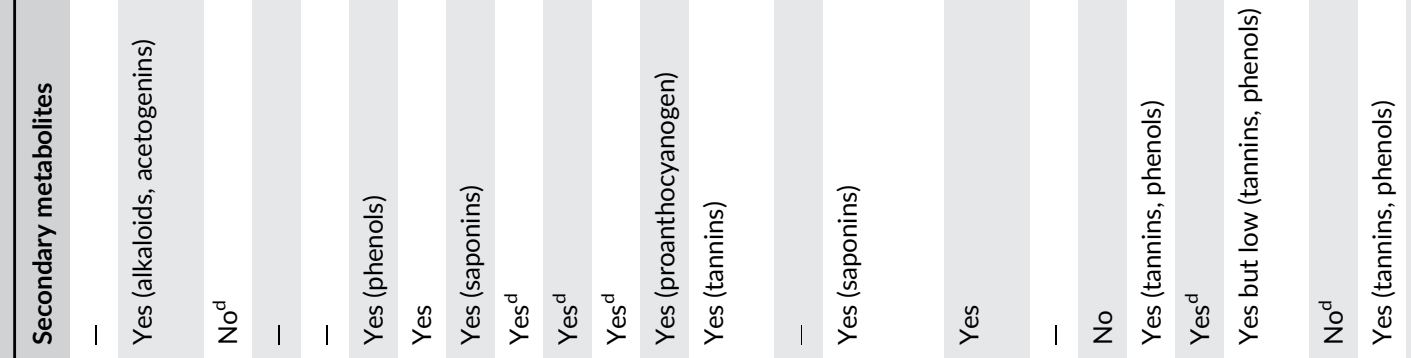

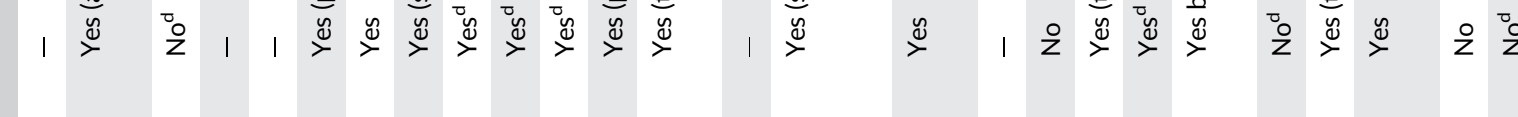

产

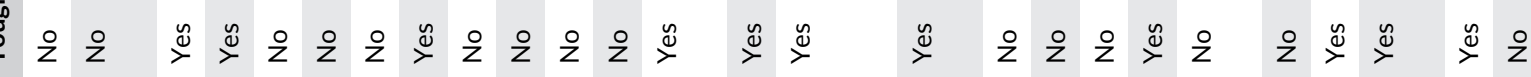

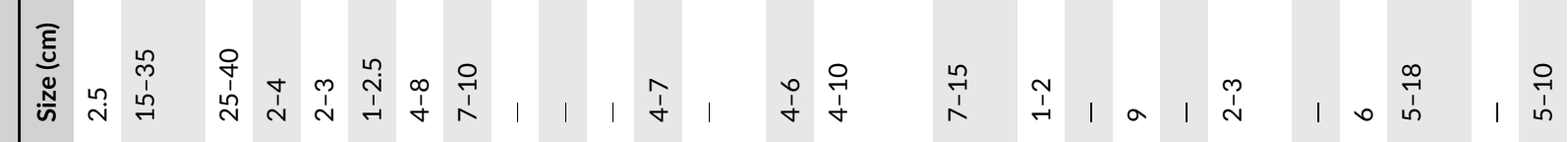

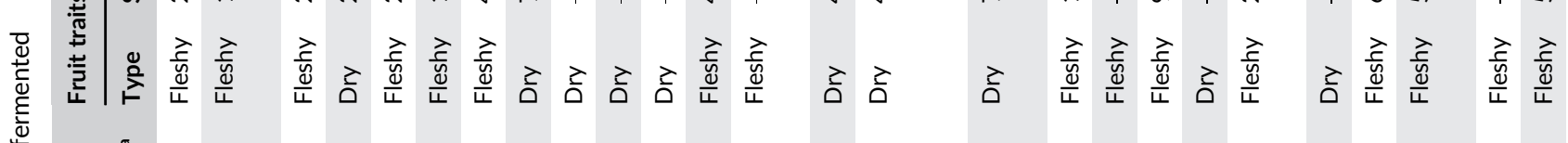
घ்

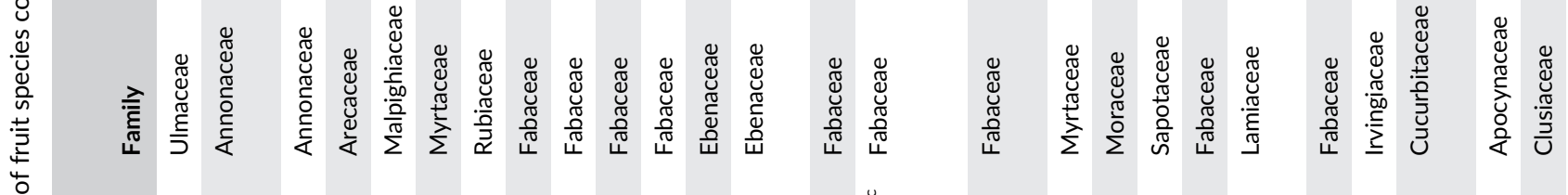

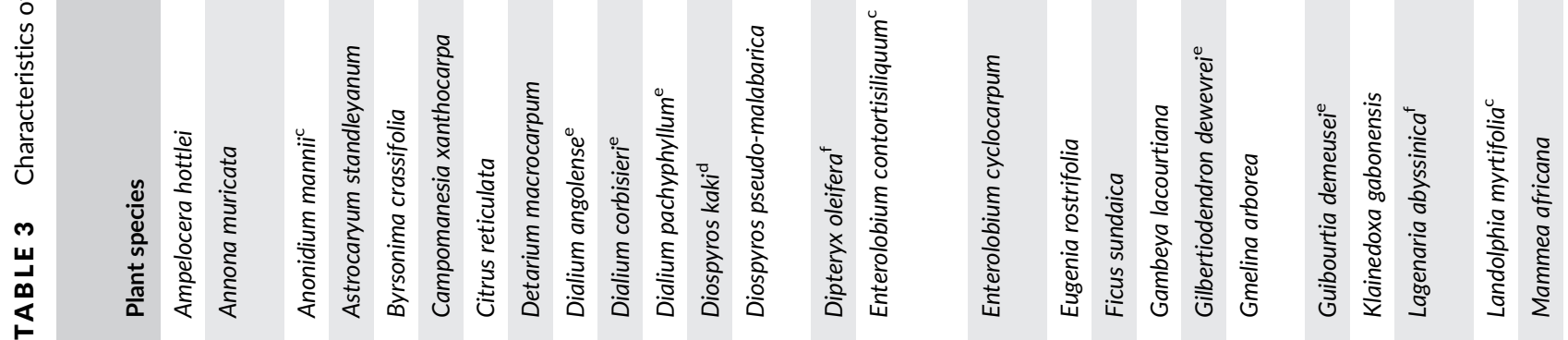




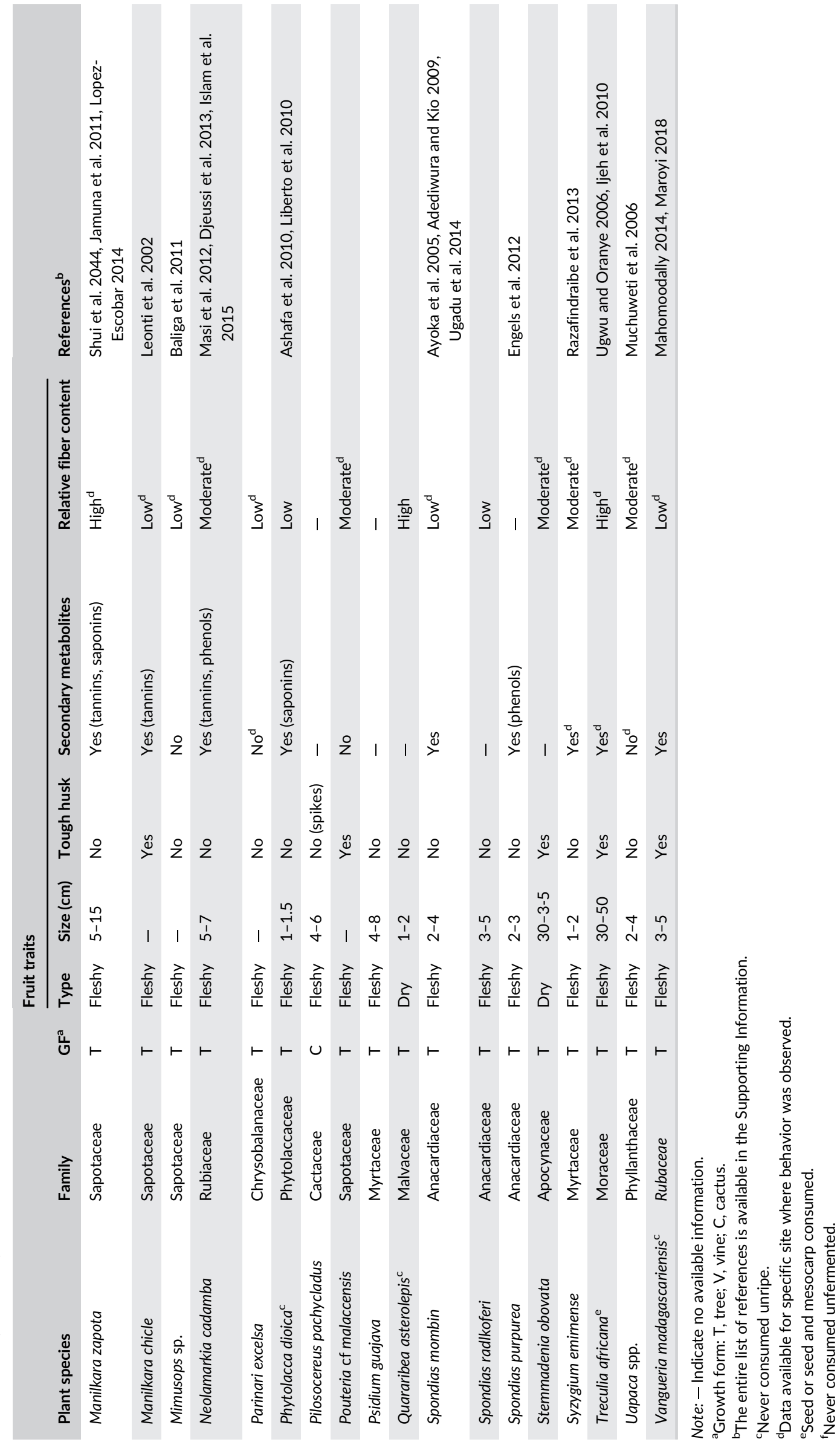




\begin{tabular}{|c|c|c|c|c|c|}
\hline \multirow{2}{*}{\multicolumn{2}{|c|}{$\begin{array}{l}\text { Predictor variables }{ }^{a} \\
\text { Best supported models }\end{array}$}} & \multicolumn{4}{|c|}{ Parameters $^{\text {b }}$} \\
\hline & & $\mathrm{AIC}_{\mathrm{c}}$ & $\Delta \mathrm{AlCc}$ & $w_{i}$ & $R_{c}^{2}$ \\
\hline \multicolumn{2}{|c|}{ 1. habitat size+rainfall+tmax+tmin } & 84.5 & 0 & 0.11 & 1.00 \\
\hline \multicolumn{2}{|l|}{ 2. habitat size+rainfall+tmax } & 84.5 & 0.02 & 0.10 & 0.99 \\
\hline \multicolumn{2}{|c|}{ 3. habitat size+longitude+rainfall+tmax } & 85.5 & 0.96 & 0.07 & 0.99 \\
\hline \multicolumn{2}{|c|}{ 4. habitat size+home range + rainfall+tmax } & 85.5 & 1.02 & 0.06 & 0.99 \\
\hline \multicolumn{2}{|c|}{ 5. habitat size+home range + rainfall+tmax+tmin } & 86.5 & 1.96 & 0.04 & 0.99 \\
\hline \multicolumn{2}{|c|}{ 6. female encephalization+habitat size+ rainfall+tmax } & 86.5 & 1.99 & 0.04 & 0.99 \\
\hline Averaged model $\left(R^{2}{ }_{c}=0.99\right)$ & $\beta_{i}$ & SE & \multicolumn{2}{|l|}{$95 \% \mathrm{Cl}$} & $\sum w_{i}$ \\
\hline Intercept & -5.2 & 2.3 & \multicolumn{2}{|c|}{$(-9.8,-0.6)$} & - \\
\hline $\operatorname{tmax}$ & 7.7 & 2.7 & \multicolumn{2}{|c|}{$(2.3,13.0)$} & 1.00 \\
\hline rainfall & -5.7 & 2.4 & \multicolumn{2}{|c|}{$(-10.5,-0.9)$} & 1.00 \\
\hline habitat size & 4.9 & 2.0 & \multicolumn{2}{|c|}{$(1.0,8.8)$} & 1.00 \\
\hline $\operatorname{tmin}$ & -4.1 & 2.0 & \multicolumn{2}{|c|}{$(-8.2,-0.1)$} & 0.35 \\
\hline longitude & 2.6 & 2.3 & \multicolumn{2}{|c|}{$(-2.0,7.2)$} & 0.16 \\
\hline home range & 1.4 & 1.1 & \multicolumn{2}{|c|}{$(-0.8,3.6)$} & 0.25 \\
\hline female encephalization & -1.1 & 2.4 & \multicolumn{2}{|c|}{$(-5.9,3.8)$} & 0.09 \\
\hline
\end{tabular}

TAB LE 4 Best linear mixed models $\left(\triangle \mathrm{AIC}_{\mathrm{c}}<2\right)$ and averaged-model that predict the consumption of fermented fruits in 40 wild primate species

${ }^{\mathrm{a}}$ Abbreviations of predictor variables: $\mathrm{tmax}=$ mean maximum ambient temperature, $\mathrm{tmin}=$ mean minimum ambient temperature, rainfall = mean annual rainfall.

${ }^{\text {b} P a r a m e t e r s ~ s h o w n ~ a r e ~ A k a i k e ' s ~ I n f o r m a t i o n ~ C r i t e r i o n ~(A I C C) ~ f o r ~ s m a l l ~ s a m p l e s, ~ d i f f e r e n c e ~ i n ~ A I C C ~}$ $(\triangle \mathrm{AICc})$, model probability Akaike weights $\left(w_{i}\right)$, Pseudo $-R^{2}\left(R_{c}^{2}\right)$ indicating the percentage of the variance explained by the fixed and random factors, partial regression coefficients of the averaged-model $\left(\beta_{i}\right)$, standard errors that incorporate model uncertainty (SE), 95\% confidence intervals for the parameter estimates, relative importance of each predictor variable $\left(\sum w_{i}\right)$. The degrees of freedom of each model are equal to the number of variables in each model plus two.

Together, these patterns are compatible with the use of targeted consumption of late-stage fermented fruits in multiple ways by primates as part of a broader nutritional strategy to increase food availability and expand their dietary niches. We found preliminary support for this interpretation. As predicted, our models indicated that latestage fermented food consumption was associated with climate and habitat patch size. In particular, late-stage fermented food consumption was more common in drier environments with more extreme mean annual maximum temperatures, as well as in larger habitat patches. Habitats with higher mean annual maximum temperatures and lower annual rainfall are potentially more nutritionally stressful for primates due to both chronic and seasonal reductions in food availability, as well as distinct plant growth strategies that result in increased mechanical and/or chemical defenses against herbivory (Coley \& Barone, 1996; Onoda et al., 2011; Poorter \& Kitajima, 2007; Zhao et al., 2013). In such environments, a primate foraging strategy that relied more heavily on late-stage fermented foods could well enhance survival during lean periods by both extending the utility of depleted food patches and increasing the digestibility of heavily defended plant foods. We do not have quantitative data relating food availability or plant-herbivore defenses to late-stage fermented food consumption across sites, precluding our ability to rigorously test this hypothesis here. However, future explorations of this relationship are warranted by our findings.

Our results also indicate other potentially important mechanisms driving patterns of primate late-stage fermented food consumption. To some extent, it appears that late-stage fermented food consumption occurs with more prevalence in habitats where primates are more likely to come into contact with fruit in the late stages of fermentation. Higher mean annual maximum temperatures are likely to result in more rapid rates of fermentation and ethanol evaporation (Isu \& Njoku, 1998), increasing the local prevalence of late-stage fermented foods and the probability that primates will detect them via olfaction (Dominy, 2004; Melin et al., 2019; Nevo \& Valenta, 2018). Furthermore, larger, potentially less fragmented, habitats are often associated with an increased abundance and diversity of fruiting trees (Abbas et al., 2011; Fahrig, 2003; Laurance et al., 2000). Therefore, there may be a higher probability that primates in these habitats will encounter fermenting fruits. However, in our dataset, the effect of habitat patch size appears to be driven by two particularly large sites, Goualougo and Mondika in the Republic of Congo. As a result, it remains unclear whether factors influencing the availability of latestage fermented foods to primates truly shape patterns of consumption more globally. 


\section{3 | Potential evolutionary benefits of late-stage fermented food consumption}

The aforementioned relationships open up new perspectives on the emergence of food fermentation as an important component of the human diet. If late-stage fermented food consumption is part of an extant primate strategy for extending the time over which a particular type of fruit can be fed on and/or increasing the nutritional accessibility of foods, particularly in nutritionally harsh environments or environments with high levels of inter-specific feeding competition, it may have served a similar role for our hominin ancestors. As hominins diverged from other primates, they began to more consistently occupy a more terrestrial niche (Sponheimer et al., 2013). It has been suggested that fermented fruits may have emerged as a fallback food in this context (Carrigan et al., 2015), and the patterns we observed in extant nonhuman primates provide some support for this hypothesis. Additionally, hominins including Paranthropus and Australopithecus are believed to have incorporated substantial amounts of hard and abrasive food items, as well as underground plant storage organs, in their diets (Dominy, 2012; Kay, 1985; Plummer, 2004; Teaford \& Ungar, 2000). Underground plant storage organs are mechanically challenging, contain more starch and fiber compared to most ripe fruits, and expose foragers to potentially high amounts of diverse secondary plant metabolites that are toxic or can interfere with digestion (Buonocore \& Silano, 1986; Dominy et al., 2008; Stahl et al., 1984; Waterman, 1984). Fermentation could have reduced both the fiber and toxin levels in these food items. In fact, fermentation is commonly used to process tubers in modern human contexts (Akinrele, 1964; Ray \& Sivakumar, 2009). While the transition to more settled, agrarian communities is often associated with the advent of human fermented food production for food preservation and ritual (Kuijt, 2009; Liu et al., 2018; Ross et al., 2002), the potential nutritional benefits of fermentation should not be underestimated. We found evidence that these benefits may be important drivers of late-stage fermented food consumption across the Order Primates.

Other nutritional and non-nutritional factors that we could not quantify should also be considered as proximate drivers of late-stage fermented food consumption in primates. First, the nutritional benefits of late-stage fermented fruits could be further improved by the presence of insects. While generally composed of small individuals, insect assemblages in fermenting fruit can be diverse and abundant (Braham, 2015; Feinstein et al., 2007; Hodge \& Arthur, 1996). Insects can provide fat, protein, vitamins, and amino acids (Xiaoming et al., 2010), and fruit infested with them are known to be selected by some primate species in other contexts (Barnett et al., 2017). Additionally, fermentation is likely to alter food taste. Anecdotal researcher taste tests in our study indicated positive changes in taste with fruit fermentation. Fermentation is generally associated with sour or acid tastes, and humans tend to prefer sweet-sour tastes (Breslin, 2013; Katz, 2012). Little is known about sour taste receptors in primates and other animals-or even sour taste preference (Montell, 2018; Roper, 2007). However, it is likely that primates share an affinity for sour taste with humans. Taste has not been systematically examined in wild primate foods, but it will likely provide additional insight into primate food choices, both fermented and unfermented.

Finally, fermented foods are likely to provide health benefits to consumers as a result of probiotic and prebiotic properties (Bourrie et al., 2016; Burton et al., 2017; Löwenadler \& Linberg, 1994; Marco et al., 2017; Summer et al., 2017; Tamang et al., 2016; Veiga et al., 2014; Yartey et al., 1995). These properties are likely to be stronger in late-stage fermented foods as a result of increased microbial activity, which may explain why these foods are targeted by some primates. Currently, without chemical and microbial data from primate foods as well as physiological and microbial data from primates, it is impossible to assess these potential relationships. However, rapidly emerging evidence of the importance of microbes for primate ecology and evolution (Amato, 2016; Amato et al., 2019; Davenport et al., 2017; Dunn et al., 2020; Gaulke et al., 2018) suggests that these interactions should not be overlooked.

\section{5 | CONCLUSION}

We find that late-stage fermented fruits are consumed by a variety of nonhuman primates globally. This behavior generally targets a specific subset of fruit species, some of which contain herbivore defenses that are likely degraded by bacterial fermentation. It also occurs more often in hotter, drier environments, and in larger habitat patches. As a result, we suggest that primate late-stage fermented food consumption may be part of a nutritional strategy that increases food availability by increasing the duration across which a particular fruit patch can be used, and expands dietary niche space by degrading some toxins in ripe fruit and providing easily accessible nutrients. It is possible that the human propensity for fermented food consumption is rooted in this ancestral primate strategy, which was favored during the course of human evolution by periods of nutritional stress caused by climate change events and migration to unknown or unfavorable landscapes. Future studies should pair systematic assessments of spatial and temporal patterns of wild primate fermented food consumption with nutritional and microbial analyses of fermented and unfermented food items to further investigate these relationships.

\section{ACKNOWLEDGMENTS}

We thank Jessica Rothman for contributing data from C. ascanius, C. guereza, L. albigena, P. anubis, and P. rufomitratus at Kibale National Park and G. beringei at Bwindi Impenetrable National Park, as well as for her input on earlier versions of the manuscript. The authors would also like to acknowledge a long list of funders, permitting agencies, and people for supporting the fieldwork associated with each field site listed. This list can be accessed in the Supplementary Material. KRA is supported as a fellow in the CIFAR "Humans and the Microbiome" program. She would also like to thank the organizers of the WennerGren Symposium \#160 "Cultures of Fermentation," held on October 11-17, 2019 (C. Warinner, J. Hendy, M. Aldenderfer, M. Rest) for sparking the idea for this paper. 


\section{AUTHOR CONTRIBUTIONS}

Oscar Chaves: Methodology; writing-review \& editing. Elizabeth Mallott: Conceptualization; methodology; writing-review \& editing. Timothy Eppley: Data curation; methodology; writing-review \& editing. Filipa Abreu: Data curation; writing-review \& editing. Andrea Baden: Data curation; writing-review \& editing. Adrian Barnett: Data curation; writing-review \& editing. Julio Cesar Bicca-Marques: Data curation; writing-review \& editing. Sarah Boyle: Data curation; writing-review \& editing. Christina Campbell: Data curation; writing-review \& editing. Colin Chapman: Data curation; writing-review \& editing. María De la Fuente: Data curation; writing-review \& editing. Pengfei Fan: Data curation; writing-review \& editing. Peter Fashing: Data curation; writing-review \& editing. Annika Felton: Data curation; writing-review \& editing. Barbara Fruth: Data curation; writing-review \& editing. Vanessa Fortes: Data curation; writing-review \& editing. Cyril Grueter: Data curation; writing-review \& editing. Gottfried Hohmann: Data curation; writing-review \& editing. Mitchell Irwin: Data curation; writing-review \& editing. Jaya Matthews: Data curation; writing-review \& editing. Addisu Mekonnen: Data curation; writing-review \& editing. Amanda Melin: Data curation; writing-review \& editing. David Morgan: Data curation; writing-review \& editing. Nga Nguyen: Data curation; writing-review \& editing. Julia Ostner: Data curation; writing-review \& editing. Alex Piel: Data curation; writing-review \& editing. Braulio Pinacho-Guendulain: Data curation; writing-review \& editing. Erika Patricia Quintino Aredes: Data curation. Patrick Razanaparany: Data curation; writing-review \& editing. Crickette Sanz: Data curation; writing-review \& editing. Nicola Schiel: Data curation; writing-review \& editing. Oliver Schülke: Data curation; writing-review \& editing. Sam Shanee: Data curation; writingreview \& editing. Antonio Souto: Data curation; writing-review \& editing. João Pedro Souza-Alves: Data curation; writing-review \& editing. Fiona Stewart: Data curation; writing-review \& editing. Kathrine Stewart: Data curation. Anita Stone: Data curation; writing-review \& editing. Binghua Sun: Data curation; writing-review \& editing. Stacey Tecot: Data curation; writing-review \& editing. Kim Valenta: Data curation; writing-review \& editing. Erin R. Vogel: Data curation; writingreview \& editing. Serge Wich: Data curation; writing-review \& editing. Yan Zeng: Data curation; methodology.

\section{CONFLICT OF INTEREST}

The authors declare no conflicts of interest.

\section{OPEN RESEARCH BAGES}

\section{(il) 6}

This article has been awarded <Open Materials, Open Data, Preregistered Research Designs $>$ badges. All materials and data are publicty accessible via the Open Science Framework at [provided URL]. Learn more about the Open Practices badges from the Center for Open Science: https://osf.io/tvyxz/wiki.

\section{DATA AVAILABILITY STATEMENT}

All data are available in the supplemental material (Table S1). The R code is also available in the supplemental material.

\section{ORCID}

Katherine R. Amato (D) https://orcid.org/0000-0003-2722-9414 Óscar M. Chaves (D) https://orcid.org/0000-0001-6246-1265

Elizabeth K. Mallott (iD https://orcid.org/0000-0001-5446-8563

Timothy M. Eppley (D) https://orcid.org/0000-0003-1456-6948

Andrea L. Baden (D) https://orcid.org/0000-0002-4722-0532

Julio Cesar Bicca-Marques (D) https://orcid.org/0000-0002-5400-845X María Fernanda De la Fuente (iD https://orcid.org/0000-0002-4137-

2404

Barbara Fruth (D) https://orcid.org/0000-0001-9217-3053

Vanessa B. Fortes (D) https://orcid.org/0000-0003-2191-6918

Cyril C. Grueter (iD) https://orcid.org/0000-0001-8770-8148

Mitchell Irwin (D) https://orcid.org/0000-0003-2088-0028

Amanda D. Melin (D) https://orcid.org/0000-0002-0612-2514

Alex K. Piel (D) https://orcid.org/0000-0002-4674-537X

Erika Patricia Quintino-Arêdes (D) https://orcid.org/0000-0001-5993-

0956

Nicola Schiel (D) https://orcid.org/0000-0002-2454-0912

Sam Shanee (D) https://orcid.org/0000-0001-5573-6208

Antonio Souto (D) https://orcid.org/0000-0003-1692-1958

João Pedro Souza-Alves (D) https://orcid.org/0000-0002-8517-1276

Fiona Stewart (D) https://orcid.org/0000-0002-4929-4711

\section{REFERENCES}

Abbas, F., Morellet, N., Hewison, A. J. M., Merlet, J., Cargnelutti, B., Lourtet, B., Angibault, J. M., Daufresne, T., Aulagnier, S., \& Verheyden, H. (2011). Landscape fragmentation generates spatial variation of diet composition and quality in a generalist herbivore. Oecologia, 167(2), 401-411.

Aiello, L. C., \& Key, C. (2002). Energetic consequences of being a Homo erectus female. American Journal of Human Biology, 14, 551-565.

Aiello, L. C., \& Wells, J. C. K. (2002). Energetics and the evolution of the genus homo. Annual Review of Anthropology, 31(1), 323-338.

Akinrele, I. (1964). Fermentation of cassava. Journal of the Science of Food and Agriculture, 15(9), 589-594.

Al Nabhani, Z., \& Eberl, G. (2020). Imprinting of the immune system by the microbiota early in life. Mucosal Immunology, 13, 183-189.

Amato, K. R. (2016). Incorporating the gut microbiota into models of human and non-human primate ecology and evolution. Yearbook of Physical Anthropology, 159, S196-S215.

Amato, K. R., Jeyakumar, T., Poinar, H., \& Gros, P. (2019). Shifting climates, foods, and diseases: The human microbiome through evolution. BioEssays, 41(10), 1900034.

Anraku, K., Nonaka, K., Yamaga, T., Yamamoto, T., Shin, M., Wakita, M., Hamamoto, A., \& Akaike, N. (2013). Removal of toxin (tetrodotoxin) from puffer ovary by traditional fermentation. Toxins, 5(1), 193-202.

Antón, S. C., Potts, R., \& Aiello, L. C. (2014). Evolution of early homo: An integrated biological perspective. Science, 345(6192), 1236828.

Barnett, A., Ronchi-Teles, B., Silva, W., Andrade, R., Almeida, T., Bezerra, B., Gonçalves de Lima, M., Spironello, W. R., MacLarnon, A., Ross, C., \& PJA, S. (2017). Covert carnivory? A seed-predating primate, the golden-backed uacari, shows preferences for insect-infested fruits. Journal of Zoological Research, 1, 16-33.

Barton, K. (2020). R package MuMIn: Model selection inference. $R$ package version, 1(43), 7. https://cran.r-project.org/web/packages/MuMln/ MuMln.pdf

Bates, D., Maechler, M., Bolker, B., \& Walker, S. (2015). Fitting linear mixed-effects models using Ime4. Journal of Statistical Software, 67 (1), 1-48. 
Battcock, M., \& Azam-Ali, S. (1998). Fermented fruits and vegetables: A global perspective. Rome: Food \& Agriculture Organization of the United Nations.

Biale, J. B. (1954). The ripening of fruit. Scientific American, 190, 40-45.

Binita, R., \& Khetarpaul, N. (1997). Probiotic fermentation: Effect on antinutrients and digestibility of starch and protein of indigenously developed food mixture. Nutrition and Health, 11(3), 139-147.

Boulton, R. B., Singleton, V. L., Bisson, L. F., \& Kunkee, R. E. (1999). Yeast and biochemistry of ethanol fermentation. In R. B. Boulton, V. L. Singleton, L. F. Bisson, \& R. E. Kunkee (Eds.), Principles and practices of winemaking (pp. 102-192). New York: Springer.

Bourrie, B. C., Willing, B. P., \& Cotter, P. D. (2016). The microbiota and health promoting characteristics of the fermented beverage kefir. Frontiers in Microbiology, 7, 647.

Brady, A. G., \& Carville, A. A. (2012). Digestive system diseases of nonhuman primates. In C. R. Abee, K. Mansfield, S. Tardiff, \& T. Morris (Eds.), Nonhuman primates in biomedical research (pp. 589-627). New York: Elsevier Inc.

Braham, M. (2015). Insect larvae associated with dropped pomegranate fruits in an organic orchard in Tunisia. Journal on Entomology and Nematology, 7, 5-10.

Breslin, P. A. (2013). An evolutionary perspective on food and human taste. Current Biology, 23(9), R409-R418.

Buonocore, V., \& Silano, V. (1986). Biochemical, nutritional and toxicological aspects of alpha-amylase inhibitors from plant foods. Advanced Experimental Medicine and Biology, 199, 483-507.

Burton, K. J., Rosikiewicz, M., Pimentel, G., Bütikofer, U., von Ah, U., Voirol, M.-J., Croxatto, A., Aeby, S., Drai, J., McTernan, P. G., Greub, G., Pralong, F. P., Vergères, G., \& Vionnet, N. (2017). Probiotic yogurt and acidified milk similarly reduce postprandial inflammation and both alter the gut microbiota of healthy, young men. British Journal of Nutrition, 117(9), 1312-1322.

Campbell, C.J. (2000). The reproductive biology of black-handed spider monkeys (Ateles geoffroyi): Integrating behavior and endocrinology. (Ph.D. Thesis), University of California, Berkeley.

Campbell, C. J., Fuentes, A., MacKinnon, K., Bearder, S., \& Stumpf, R. (2011). Primates in perspective (2nd ed.). New York: Oxford University Press.

Campbell-Platt, G. (1994). Fermented foods-A world perspective. Food Research International, 27(3), 253-257.

Carrigan, M. A., Uryasev, O., Frye, C. B., Eckman, B. L., Myers, C. R., Hurley, T. D., \& Benner, S. A. (2015). Hominids adapted to metabolize ethanol long before human-directed fermentation. Proceedings of the National Academy of Sciences, 112(2), 458-463.

Chaves-López, C., Serio, A., Grande-Tovar, C. D., Cuervo-Mulet, R. Delgado-Ospina, J., \& Paparella, A. (2014). Traditional fermented foods and beverages from a microbiological and nutritional perspective: The Colombian heritage. Comprehensive Reviews in Food Science and Food Safety, 13(5), 1031-1048.

Cipollini, M. L., \& Levey, D. J. (1997). Why are some fruits toxic? Glycoalkaloids in solanumand fruit choice by vertebrates. Ecology, 78 (3), 782-798.

Clutton-Brock, T. H., \& Harvey, P. H. (1980). Primates, brains and ecology Journal of Zoology, 190(3), 309-323.

Coley, P. D., \& Barone, J. (1996). Herbivory and plant defenses in tropical forests. Annual Review of Ecology and Systematics, 27(1), 305-335.

Cryan, J. F., O'Riordan, K. J., Cowan, C. S., Sandhu, K. V., Bastiaanssen, T. F., Boehme, M., Codagnone, M. G., Cussotto, S., Fulling, C., Golubeva, A. V., Guzzetta, K. E., Jaggar, M., LongSmith, C. M., Lyte, J. M., Martin, J. A., Molinero-Perez, A., Moloney, G., Morelli, E., Morillas, E., ... Dinan, T. G. (2019). The microbiotagut-brain axis. Physiological Reviews, 99(4), 1877-2013.

Dausch Ibañez, D., Hernandez Salazar, L. T., \& Laska, M. (2019). Taste responsiveness of spider monkeys to dietary ethanol. Chemical Senses, 44(8), 631-638.
Davenport, E. R., Sanders, J. G., Song, S. J., Amato, K. R., Clark, A. G., \& Knight, R. (2017). The human microbiome in evolution. BMC Biology, 15, 127.

Davies, A., \& Oates, J. (1994). Colobine monkeys: Their ecology, behavior and evolution. New York: Cambridge University Press.

DeCasien, A. R., Williams, S. A., \& Higham, J. P. (2017). Primate brain size is predicted by diet but not sociality. Nature Ecology \& Evolution, 1 (5), 1-7.

Deshpande, S. (2000). Fermented grain legumes, seeds and nuts: A global perspective. Rome: Food \& Agriculture Organization of the United Nations.

Dominy, N. (2012). Hominins living on the sedge. Proceedings of the National Academy of Science, 109(50), 20171-20172.

Dominy, N., Vogel, E. R., Yeakel, J. D., Constantino, P., \& Lucas, P. W. (2008). Mechanical properties of plant underground storage organs and implications for dietary models of early hominins. Evolutionary Biology, 35(3), 159-175.

Dominy, N. J. (2004). Fruits, fingers, and fermentation: The sensory cues available to foraging primates. Integrative and Comparative Biology, 44 (4), 295-303.

Dominy, N. J. (2015). Ferment in the family tree. Proceedings of the National Academy of Sciences, 112(2), 308-309.

Duar, R. M., Lin, X. B., Zheng, J., Martino, M. E., Grenier, T., Pérezmuñoz, M. E., Leulier, F., Gänzle, M., \& Walter, J. (2017). Lifestyles in transition: Evolution and natural history of the genus lactobacillus. FEMS Microbiology Reviews, 41, S27-S48.

Dudley, R. (2002). Fermenting fruit and the historical ecology of ethanol ingestion: Is alcoholism in modern humans an evolutionary hangover? Addiction, 97(4), 381-388.

Dudley, R. (2004). Ethanol, fruit ripening, and the historical origins of human alcoholism in primate frugivory. Integrative and Comparative Biology, 44(4), 315-323.

Dudley, R. (2014). The drunken monkey: Why we drink and abuse alcohol. Los Angeles: University of California Press.

Dunbar, R., \& Shultz, S. (2017). Why are there so many explanations for primate brain evolution? Philosophical Transactions of the Royal Society, B: Biological Sciences, 372(1727), 20160244.

Dunbar, R. I. M., \& Shultz, S. (2007). Understanding primate brain evolution. Philosophical Transactions of the Royal Society B, 362, 649-658.

Dunn, R. R., Amato, K. R., Archie, E. A., Arandjelovic, M., Crittenden, A. N., \& Nichols, L. M. (2020). The internal, external and extended microbiomes of hominins. Frontiers in Ecology and Evolution, 8,25 .

Estrada, A., Garber, P. A., Rylands, A. B., Roos, C., Fernandez-Duque, E., di Fiore, A., Nekaris, K. A. I., Nijman, V., Heymann, E. W., Lambert, J. E., Rovero, F., Barelli, C., Setchell, J. M., Gillespie, T. R., Mittermeier, R. A., Arregoitia, L. V., de Guinea, M., Gouveia, S., Dobrovolski, R., ... Li, B. (2017). Impending extinction crisis of the world's primates: Why primates matter. Science Advances, 3(1), e1600946.

Fahrig, L. (2003). Effects of habitat fragmentation on biodiversity. Annual Review of Ecological and Evolutionary Systems, 34, 487-515.

Feinstein, J., Mori, S., \& Berkov, A. (2007). Saproflorivory: A diverse insect community in fallen flowers of Lecythidaceae in French Guiana. Biotropica, 39(4), 549-554.

Felton, A., Felton, A., Wood, J., Foley, W., Raubenheimer, D., Wallis, I., \& Lindenmayer, D. (2009). Nutritional ecology of Ateles chamek in lowland Bolivia: How macronutrient balancing influences food choices. International Journal of Primatology, 30(5), 675-696.

Garnier, N., \& Valamoti, S. M. (2016). Prehistoric wine-making at Dikili Tash (northern Greece): Integrating residue analysis and archaeobotany. Journal of Archaeological Science, 74, 195-206.

Gaulke, C. A., Arnold, H. K., Humphreys, I. R., Kembel, S. W., O'Dwyer, J. P., \& Sharpton, T. J. (2018). Ecophylogenetics clarifies the 
evolutionary association between mammals and their gut microbiota. MBio, 9(5), e01348-e01318.

Gobbetti, M., Simonetti, M., Rossi, J., Cossignani, L., Corsetti, A., \& Damiani, P. (1994). Free D-and L-amino acid evolution during sourdough fermentation and baking. Journal of Food Science, 59(4), 881-884.

Gochman, S. R., Brown, M. B., \& Dominy, N. J. (2016). Alcohol discrimination and preferences in two species of nectar-feeding primate. Royal Society Open Science, 3(7), 160217.

Gorgus, E., Hittinger, M., \& Schrenk, D. (2016). Estimates of ethanol exposure in children from food not labeled as alcohol-containing. Journal of Analytical Toxicology, 40(7), 537-542.

Grueber, C., Nakagawa, S., Laws, R., \& Jamieson, I. (2011). Multimodel inference in ecology and evolution: Challenges and solutions. Journal of Evolutionary Biology, 24(4), 699-711.

Gupta, R. K., Gangoliya, S. S., \& Singh, N. K. (2015). Reduction of phytic acid and enhancement of bioavailable micronutrients in food grains. Journal of Food Science and Technology, 52(2), 676-684.

Hayden, B., Canuel, N., \& Shanse, J. (2013). What was brewing in the Natufian? An archaeological assessment of brewing technology in the Epipaleolithic. Journal of Archaeological Method and Theory, 20(1), 102-150.

Hockings, K. J., Bryson-Morrison, N., Carvalho, S., Fujisawa, M., Humle, T., McGrew, W. C., Nakamura, M., Ohashi, G., Yamanashi, Y., Yamakoshi, G., \& Matsuzawa, T. (2015). Tools to tipple: Ethanol ingestion by wild chimpanzees using leaf-sponges. Royal Society Open Science, 2(6), 150150.

Hodge, S., \& Arthur, W. (1996). Insect invasion sequences: Systematic or stochastic? Ecological Entomology, 21(2), 150-154.

Isu, N., \& Njoku, H. (1998). Studies on the influence of temperature, relative humidity and microenvironment on the natural fermentation of African oil bean seeds to 'Ugba'. Plant Foods for Human Nutrition, 52 (4), 337-351.

Jacobsen, C. N., Rosenfeldt Nielsen, V., Hayford, A., Møller, P. L., Michaelsen, K., Pærregaard, A., Sandström, B., Tvede, M., \& Jakobsen, M. (1999). Screening of probiotic activities of forty-seven strains of Lactobacillus spp. by in vitro techniques and evaluation of the colonization ability of five selected strains in humans. Applied and Environmental Microbiology, 65(11), 4949-4956.

Janiak, M. C., Pinto, S. L., Duytschaever, G., Carrigan, M. A., \& Melin, A. D. (2020). Genetic evidence of widespread variation in ethanol metabolism among mammals: Revisiting the 'myth'of natural intoxication. Biology Letters, 16(4), 20200070.

Janzen, D. H. (1983). Physiological ecology of fruits and their seeds. In O. Lange, P. Nobel, C. Osmond, \& H. Ziegler (Eds.), Physiological plant ecology III (pp. 625-655). Berlin: Springer.

Katz, S. E. (2012). The art of fermentation: An in-depth exploration of essential concepts and processes from around the world. White River Junction: Chelsea Green Publishing.

Kay, R. F. (1985). Dental evidence for the diet of Australopithecus. Annual Review of Anthropology, 14(1), 315-341.

Kim, J., Choi, E., Hong, Y., Song, Y., Han, J., Lee, S., Han, E. S., Kim, T. W., Choi, I. S., \& Cho, K. (2016). Changes in Korean adult females' intestinal microbiota resulting from kimchi intake. Journal of Nutrition \& Food Sciences, 6, 4172.

Kornet, M., Goosen, C., Ribbens, L. G., \& Van Ree, J. M. (1990). Analysis of spontaneous alcohol drinking in rhesus monkeys. Physiology \& Behavior, 47(4), 679-684.

Kudo, H., \& Dunbar, R. I. M. (2001). Neocortex size and social network size in primates. Animal Behavior, 62(4), 711-722.

Kuijt, I. (2009). What do we really know about food storage, surplus, and feasting in preagricultural communities? Current Anthropology, 50(5), 641-644.

Laurance, W. F., Delamonica, P., Laurance, S. G., Vasconcelos, H. L., \& Lovejoy, T. E. (2000). Rainforest fragmentation kills big trees. Nature, 404, 806.
LeBlanc, J. G., Milani, C., de Giori, G. S., Sesma, F., van Sinderen, D., \& Ventura, M. (2013). Bacteria as vitamin suppliers to their host: A gut microbiota perspective. Current Opinion in Biotechnology, 24(2), 160-168.

Leonard, W. R., \& Robertson, J. (1997). Comparative primate energetics and hominid evolution. American Journal of Physical Anthropology, 102 (2), 265-281.

Leonard, W. R., \& Robertson, M. (1992). Nutritional requirements and human evolution: A bioenergetics model. American Journal of Human Biology, 4, 179-195.

Liu, L., Wang, J., Rosenberg, D., Zhao, H., Lengyel, G., \& Nadel, D. (2018). Fermented beverage and food storage in 13,000 y-old stone mortars at Raqefet cave, Israel: Investigating Natufian ritual feasting. Journal of Archaeological Science: Reports, 21, 783-793.

López, O. (2001). Seed flotation and postflooding germination in tropical terra firme and seasonally flooded forest species. Functional Ecology, 15, 763-771.

Löwenadler, J., \& Linberg, C. L. (1994). Study of locally prepared lactic acid fermented weaning food in Tanzania -presence of diarrhoeal pathogens. A minor field study. [Working Paper]. International Rural Development Center: Swedish University of Agricultural Sciences, Sweden.

Maldonado-Gómez, M. X., Martínez, I., Bottacini, F., O'Callaghan, A., Ventura, M., van Sinderen, D., Hillmann, B., Vangay, P., Knights, D., Hutkins, R. W., \& Walter, J. (2016). Stable engraftment of Bifidobacterium longum $\mathrm{AH} 1206$ in the human gut depends on individualized features of the resident microbiome. Cell Host \& Microbe, 20(4), 515-526.

Mandillo, S., Titchen, K., \& Miczek, K. A. (1998). Ethanol drinking in socially housed squirrel monkeys. Behavioural Pharmacology, 9(4), 363-368.

Marco, M. L., Heeney, D., Binda, S., Cifelli, C. J., Cotter, P. D., Foligné, B., Gänzle, M., Kort, R., Pasin, G., Pihlanto, A., Smid, E. J., \& Hutkins, R. (2017). Health benefits of fermented foods: Microbiota and beyond. Current Opinion in Biotechnology, 44, 94-102.

Martinson, E. O., Herre, E. A., Machado, C. A., \& Arnold, A. E. (2012). Culture-free survey reveals diverse and distinctive fungal communities associated with developing figs (Ficus spp.) in Panama. Microbial Ecology, 64(4), 1073-1084.

Melin, A. D., Nevo, O., Shirasu, M., Williamson, R. E., Garrett, E. C., Endo, M., Sakurai, K., Matsushita, Y., Touhara, K., \& Shoji, K. (2019). Fruit scent and observer colour vision shape food-selection strategies in wild capuchin monkeys. Nature Communications, 1, 2407.

Milton, K. (2004). Ferment in the family tree: Does a frugivorous dietary heritage influence contemporary patterns of human ethanol use? Integrative and Comparative Biology, 44(4), 304-314.

Mitchell, M. C., \& Herlong, H. F. (1986). Alcohol and nutrition: Caloric value, bioenergetics, and relationship to liver damage. Annual Review of Nutrition, 6(1), 457-474.

Montell, C. (2018). pHirst sour taste channels pHound? Science, 359 (6379), 991-992.

Naimi, B., Hamm, N. A., Groen, T. A., Skidmore, A. K., \& Toxopeus, A. G. (2014). Where is positional uncertainty a problem for species distribution modelling? Ecography, 37(2), 191-203.

Nayak, B. S., Dinda, S. C., \& Ellaiah, P. (2013). Evaluation of diuretic activity of Gmelina arborea Roxb. fruit extracts. Asian Journal of Pharmaceutical and Clinical Research, 6(1), 111-113.

Nevo, O., \& Valenta, K. (2018). The ecology and evolution of fruit odor: Implications for primate seed dispersal. International Journal of Primatology, 39(3), 338-355.

NRC. (1998). Lost crops of Africa: Volume I: Grains. National Resource Council, Washington, D.C.: National Academies Press.

NRC. (2003). Nutrient requirements of nonhuman primates. National Resource Council, Washington, D.C.: National Academies Press.

Nyanga, L. K., Nout, M. J., Gadaga, T. H., Theelen, B., Boekhout, T., \& Zwietering, M. H. (2007). Yeasts and lactic acid bacteria microbiota from 
masau (Ziziphus mauritiana) fruits and their fermented fruit pulp in Zimbabwe. International Journal of Food Microbiology, 120(1-2), 159-166.

Oliphant, K., \& Allen-Vercoe, E. (2019). Macronutrient metabolism by the human gut microbiome: Major fermentation by-products and their impact on host health. Microbiome, 7(1), 91.

Onoda, Y., Westoby, M., Adler, P. B., Choong, A. M., Clissold, F. J., Cornelissen, J. H., Díaz, S., Dominy, N. J., Elgart, A., Enrico, L., Fine, P. V. A., Howard, J. J., Jalili, A., Kitajima, K., Kurokawa, H., McArthur, C., Lucas, P. W., Markesteijn, L., Pérez-Harguindeguy, N., .. Yamashita, N. (2011). Global patterns of leaf mechanical properties. Ecology Letters, 14(3), 301-312.

Peters, A., Krumbholz, P., Jäger, E., Heintz-Buschart, A., Çakir, M. V., Rothemund, S., Gaudl, A., Ceglarek, U., Schöneberg, T., \& Stäubert, C. (2019). Metabolites of lactic acid bacteria present in fermented foods are highly potent agonists of human hydroxycarboxylic acid receptor 3. PLoS Genetics, 15(5), e1008145.

Plummer, T. (2004). Flaked stones and old bones: Biological and cultural evolution at the dawn of technology. Yearbook of Physical Anthropology, 47, 118-164.

Poorter, L., \& Kitajima, K. (2007). Carbohydrate storage and light requirements of tropical moist and dry forest tree species. Ecology, 88(4), 1000-1011.

Pretorius, I. S. (2000). Tailoring wine yeast for the new millennium: Novel approaches to the ancient art of winemaking. Yeast, 16(8), 675-729.

$R$ Core Team. (2020). $R$ : A language and environment for statistical computing (version 3.6.3). Vienna, Austria: R Foundation for Statistical Computing.

Ray, R. C., \& Sivakumar, P. S. (2009). Traditional and novel fermented foods and beverages from tropical root and tuber crops. International Journal of Food Science \& Technology, 44(6), 1073-1087.

Rollan, G. C., Gerez, C. L., \& LeBlanc, J. G. (2019). Lactic fermentation as a strategy to improve the nutritional and functional values of pseudocereals. Frontiers in Nutrition, 6, 1-16.

Roper, S. D. (2007). Signal transduction and information processing in mammalian taste buds. Pflügers Archiv - European Journal of Physiology, 454(5), 759-776.

Ross, R. P., Morgan, S., \& Hill, C. (2002). Preservation and fermentation: Past. present and future. International Journal of Food Microbiology, 79, 3-16.

Rowe, M. H. (2018). Trichromatic color vision in primates. Physiology, 17, 93-98.

Rowe, N., \& Myers, M. (2016). All the world's primates. Charlestown: Pogonias Press.

Ruiz Rodriguez, L. G., Mohamed, F., Bleckwedel, J., Medina, R. B., De Vuyst, L., Hebert, E. M., \& Mozzi, F. (2019). Diversity and functional properties of lactic acid bacteria isolated from wild fruits and flowers present in northern Argentina. Frontiers in Microbiology, 10, 1091.

Skinner, F. A., Passmore, S. M., \& Davenport, R. (1980). Biology and activities of yeasts. London: Academic Press.

Smalley, J., \& Blake, M. (2003). Sweet beginnings: Stalk sugar and the domestication of maize. Current Anthropology, 44(5), 675-703.

Souza-Alves, J. P., Mourthe, I., Hilário, R. R., Bicca-Marques, J. C., Rehg, J., Gestich, C. C., Acero-Murcia, A. C., Adret, P., Aquino, R., Berthet, M., Bowler, M., Calouro, A. M., Canale, G. R., Cardoso, N. . A., Caselli, C. B., Cäsar, C., Chagas, R. R. D., Clyvia, A., Corsini, C. F., ... Barnett, A. A. (2019). Terrestrial behavior in titi monkeys (Callicebus, Cheracebus, and Plecturocebus): Potential correlates, patterns, and differences between genera. International Journal of Primatology, 40, 553-572.

Speth, J. D. (2017). Putrid meat and fish in the eurasian middle and upper paleolithic: Are we missing a key part of neanderthal and modern human diet? PaleoAnthropology, 2017, 44-72.

Sponheimer, M., Alemseged, Z., Cerling, T. E., Grine, F. E., Kimbel, W. H., Leakey, M. G., Lee-Thorp, J. A., Manthi, F. K., Reed, K. E.,
Wood, B. A., \& Wynn, J. G. (2013). Isotopic evidence of early hominin diets. Proceedings of the National Academy of Science, 110, 10513-10518.

Stahl, A. B., Dunbar, R., Homewood, K., Ikawa-Smith, F., Kortlandt, A., McGrew, W., Milton, K., Paterson, J. D., Poirier, F. E., Sugardjito, J., Tanner, N. M., \& Wrangham, R. W. (1984). Hominid dietary selection before fire [and comments and reply]. Current Anthropology, 25(2), 151-168.

Strier, K. B. (2016). Primate behavioral ecology. New York: Routledge.

Summer, A., Formaggioni, P., Franceschi, P., Di Frangia, F., Righi, F., \& Malacarne, M. (2017). Cheese as functional food: The example of parmigiano reggiano and grana padano. Food Technology and Biotechnology, 55(3), 277-289.

Sussman, R. W. (1991). Primate origins and the evolution of angiosperms. American Journal of Primatology, 23(4), 209-223.

Sylvia, K. E., \& Demas, G. E. (2018). A gut feeling: Microbiome-brainimmune interactions modulate social and affective behaviors. Hormones and Behavior, 99, 41-49.

Tamang, J., \& Kailasapathy, K. (2010). Fermented foods and beverages of the world. Boca Raton: CRC Press.

Tamang, J. P., Holzapfel, W. H., Shin, D. H., \& Felis, G. E. (2017). Microbiology of ethnic fermented foods and alcoholic beverages of the world. Frontiers in Microbiology, 8, 1377.

Tamang, J. P., Shin, D.-H., Jung, S.-J., \& Chae, S.-W. (2016). Functional properties of microorganisms in fermented foods. Frontiers in Microbiology, 7, 578

Teaford, M., \& Ungar, P. (2000). Diet and the evolution of the earliest human ancestors. Proceedings of the National Academy of Science, 97 (25), 13506-13511.

Thomson, J. M., Gaucher, E. A., Burgan, M. F., De Kee, D. W., Li, T., Aris, J. P., \& Benner, S. A. (2005). Resurrecting ancestral alcohol dehydrogenases from yeast. Nature Genetics, 37(6), 630-635.

Veiga, P., Pons, N., Agrawal, A., Oozeer, R., Guyonnet, D., Brazeilles, R., Ehrlich, S. D., \& Whorwell, P. J. (2014). Changes of the human gut microbiome induced by a fermented milk product. Scientific Reports, 4 , 6328.

Visconti, A., Le Roy, C. I., Rosa, F., Rossi, N., Martin, T. C., Mohney, R. P., Li, W., de Rinaldis, E., Bell, J. T., Venter, J. C., Nelson, K. E., Spector, T. D., \& Falchi, M. (2019). Interplay between the human gut microbiome and host metabolism. Nature Communications, 10 (1), 1-10.

Waterman, P. G. (1984). Food acquisition and processing as a function of plant chemistry. In D. J. Chivers, B. A. Wood, \& A. Bilsborough (Eds.), Food acquisition and processing in primates (pp. 177-211). Boston: Springer.

Weaver, V. R. (2016). Dietary ethanol ingestion by free ranging spider monkeys (Ateles geoffroyi): An evalution of the drunken monkey hypothesis. (unpublished master's thesis), California State University, Northridge.

Wiens, F., Zitzmann, A., Lachance, M.-A., Yegles, M., Pragst, F., Wurst, F. M., von Holst, D., Guan, S. L., \& Spanagel, R. (2008). Chronic intake of fermented floral nectar by wild treeshrews. Proceedings of the National Academy of Sciences, 105(30), 10426-10431.

Wrangham, R., \& Waterman, P. (1983). Condensed tannins in fruits eaten by chimpanzees. Biotropica, 15(3), 217-222.

Wrangham, R. W. (2009). Catching fire: How cooking made us human. New York: Basic Books.

Wrangham, R. W., \& Conklin-Brittain, N. L. (2003). Cooking as a biological trait. Comparative Biochemistry and Physiology, 136(1), 35-46.

Xiaoming, C., Ying, F., Hong, Z., \& Zhiyong, C. (2010). Review of the nutritive value of edible insects. In P. B. Drust, D. V. Johnson, R. N. Leslie, \& K. Shono (Eds.), Forest insects as food: Humans bite back (pp. 85-92). Bangkok, Thailand: Food and Agriculture Organization of the United Nations. 
Yartey, J., Nkrumah, F., Hori, H., Harrison, K., \& Armar, D. (1995). Clinical trial of fermented maize-based oral rehydration solution in the management of acute diarrhoea in children. Annals of Tropical Paediatrics, 15(1), 61-68.

Zhao, J., Hartmann, H., Trumbore, S., Ziegler, W., \& Zhang, Y. (2013). High temperature causes negative whole-plant carbon balance under mild drought. New Phytologist, 200(2), 330-339.

Zuur, A. F., leno, E. N., Walker, N. J., Saveliev, A. A., \& Smith, G. M. (2009). GLM and GAM for count data. In A. Zuur, E. N. leno, N. Walker, A. A. Saveliev, \& G. M. Smith (Eds.), Mixed effects models and extensions in ecology with $R$ (pp. 209-243). New York: Springer.

\section{SUPPORTING INFORMATION}

Additional supporting information may be found online in the Supporting Information section at the end of this article.

How to cite this article: Amato KR, Chaves ÓM, Mallott EK, et al. Fermented food consumption in wild nonhuman primates and its ecological drivers. Am J Phys Anthropol. 2021;

1-18. https://doi.org/10.1002/ajpa.24257 